\title{
Thirty Years of Land Use/Land Cover Changes and Their Impact on Urban Climate: A Study of Kano Metropolis, Nigeria
}

\author{
Auwalu Faisal Koko ${ }^{1}\left(\mathbb{D}\right.$, Yue $\mathrm{Wu}^{1,2, *}$, Ghali Abdullahi Abubakar $\left.{ }^{3}{ }^{(}\right)$, Akram Ahmed Noman Alabsi ${ }^{1}\left({ }^{(}\right.$, \\ Roknisadeh Hamed ${ }^{1}$ and Muhammed Bello ${ }^{4}$ \\ 1 College of Civil Engineering and Architecture, Zhejiang University, Hangzhou 310058, China; \\ 11812112@zju.edu.cn (A.F.K.); 11612071@zju.edu.cn (A.A.N.A.); h.roknizadej@zju.edu.cn (R.H.) \\ 2 International Center for Architecture and Urban Development Studies, Zhejiang University, \\ Hangzhou 310058, China \\ 3 Institute of Applied Remote Sensing and Information Technology, College of Environmental and Resource \\ Sciences, Zhejiang University, Hangzhou 310058, China; ghaliaa@zju.edu.cn \\ 4 Department of Architecture, Kaduna Polytechnic, P. M. B. 2021, Kaduna 800262, Nigeria; \\ mbello02@kadunapolytechnic.edu.ng \\ * Correspondence: ywu100@zju.edu.cn
}

\section{check for} updates

Citation: Koko, A.F.; Wu, Y.; Abubakar, G.A.; Alabsi, A.A.N.; Hamed, R.; Bello, M. Thirty Years of Land Use/Land Cover Changes and Their Impact on Urban Climate: A Study of Kano Metropolis, Nigeria. Land 2021, 10, 1106. https://doi.org/ 10.3390/land10111106

Academic Editors: Nicola Genzano, Maria Lanfredi, Giuseppe Mazzeo and Ramesh P. Singh

Received: 16 September 2021

Accepted: 16 October 2021

Published: 20 October 2021

Publisher's Note: MDPI stays neutral with regard to jurisdictional claims in published maps and institutional affiliations.

Copyright: (c) 2021 by the authors. Licensee MDPI, Basel, Switzerland. This article is an open access article distributed under the terms and conditions of the Creative Commons Attribution (CC BY) license (https:// creativecommons.org/licenses/by/ $4.0 /)$.

\begin{abstract}
Rapid urban expansion and the alteration of global land use/land cover (LULC) patterns have contributed substantially to the modification of urban climate, due to variations in Land Surface Temperature (LST). In this study, the LULC change dynamics of Kano metropolis, Nigeria, were analysed over the last three decades, i.e., 1990-2020, using multispectral satellite data to understand the impact of urbanization on LST in the study area. The Maximum Likelihood classification method and the Mono-window algorithm were utilised in classifying land uses and retrieving LST data. Spectral indices comprising the Normalized Difference Vegetation Index (NDVI) and Normalized Difference Built-up Index (NDBI) were also computed. A linear regression analysis was employed in order to examine the correlation between land surface temperature and the various spectral indices. The results indicate significant LULC changes and urban expansion of $152.55 \mathrm{sq} . \mathrm{km}$ from 1991 to 2020. During the study period, the city's barren land and water bodies declined by approximately $172.58 \mathrm{sq}$. $\mathrm{km}$ and $26.55 \mathrm{sq}$. km, respectively, while vegetation increased slightly by 46.58 sq. km. Further analysis showed a negative correlation between NDVI and LST with a Pearson determination coefficient $\left(R^{2}\right)$ of $0.6145,0.5644,0.5402$, and 0.5184 in 1991, 2000, 2010, and 2020 respectively. NDBI correlated positively with LST, having an $R^{2}$ of 0.4132 in 1991, 0.3965 in 2000, 0.3907 in 2010, and 0.3300 in 2020 . The findings of this study provide critical climatic data useful to policy- and decision-makers in optimizing land use and mitigating the impact of urban heat through sustainable urban development.
\end{abstract}

Keywords: land-use change; urban expansion; urban climate; geospatial mapping; spectral indices; remote sensing; GIS

\section{Introduction}

The rapid increase in the global rate of urbanisation and subsequent changes in the land use/land covers (LULC) of different cities have substantially influenced the conditions of urban environments [1-6]. The various changes in land use attributed to the remarkable growth and expansion of urban areas have continuously attracted widespread global concern, especially in cities of the developed and developing countries, mainly as a result of the massive reduction in biodiversity, alteration of local climatic conditions, and development of surface urban heat islands (UHI) [7-9]. The consequences of these trends have led to a decrease in air quality, compromised water resources [10], increased energy consumption [11,12], and damage to human health due to the higher heat stress associated with increased land temperatures in urban centers [13-15]. Other environmental 
consequences of land-use changes include the breakdown of ecological cycles and an increase in greenhouse gas emissions that contribute to climate change [16-18]. Therefore, it is evident that urban expansion due to population growth has contributed significantly to the transformation of urban climate.

Globally, the urban population has increased rapidly over the last few decades, from only $30 \%$ in 1950 to over 55\% in 2018 [19]. United Nations estimates indicate that in the next 29 years, i.e., in 2050, the global urban population can be expected to rise above $68 \%$. The highest growth is anticipated to occur predominantly in Asia and Africa. Countries like India, China, and Nigeria will have an estimated urban population of approximately 416 million, 255 million, and 189 million, respectively [20]. This growth could increase land surface temperatures, leading to the development of Urban Heat Islands (UHI) in these geographical areas [21]. The emergence of urban heat islands that influence urban climate can be attributed to the transformation of land uses and the rapid urbanisation of cities [22-25]. Urban Heat Islands have gradually become a common global theme, with LST increasing faster in urban centers than in rural areas [26-30]. This phenomenon mainly results from the transition of vegetated lands into impervious surfaces covered by buildings, roads, and other infrastructural facilities [31]. The generation of anthropogenic heat from industrial plants, automobile exhaust, and other urban heating and cooling facilities has also contributed to the development of UHI effects [32-34]. The consequences have influenced the urban environment and quality of life $[35,36]$.

Therefore, studies on urban climatic management have become imperative, particularly in rapidly growing cities seeking to mitigate climate change and achieve sustainable urban development. Some studies have monitored the impact of land-use alterations on urban climatic conditions, employing LST data and spectral indices that include NDVI, NDBI, and many others. In a study conducted in Noida city, India, the connection between land cover changes and UHI was assessed using a statistical Pearson correlation of LST against NDVI, NDBI, Albedo, and Emissivity [30]. The study's result revealed that the change in Nodia City's temperature were mainly attributed to the increase in the city's impervious areas. Similarly, the spatio-temporal effect of LULC alterations on the surface UHI of Kandy City, Sri Lanka, was monitored between 1996 and 2017 [37]. The result revealed a persistent increase in impervious surfaces and a decreasing trend in the spatial extent of forest areas that contributed to the mean LST increase of the study. In Odisha City, India, $25-50 \%$ of the overall warming observed between 1981 and 2010 was attributed to changes in land uses, with vegetational decrease contributing significantly to human-induced warming [38]. The micro-climate of the Bangkok metropolitan region in Thailand was recently estimated relative to the city's future expansion [39]. The results showed that modification of the vegetated areas in the city's western region with low-rise and mid-rise buildings would increase the future surface temperature of the region by approximately 1 to $2{ }^{\circ} \mathrm{C}$. Other studies conducted in Nigeria's cities of Abuja [21] and Potiskum [40], China's urban area of Shenzhen [41], Turkey's Sivas City [23], and five coastal cities in Pakistan [42] have demonstrated the relationship between LULC changes and LST using various satellite data and GIS techniques. However, comprehensive studies of cities in developing countries such as Nigeria are still limited. Urban centres such as Kano Metropolis lack up to date studies on the growing influence of land use/land cover changes to the local climate. Kano, the economic, commercial, and agriculture hub of Northern Nigeria, has been growing rapidly and experienced one of the highest urbanisation rates in Africa's most populous country. The metropolis has seen its population increase by about 1.98 million inhabitants over the last three decades, leading to various land use alterations. Therefore, this study analyses thirty years of LULC changes and their impact on urban climate using remotely sensed data. The study aims to monitor the influence of LULC changes on the LST of Kano metropolis between 1990 and 2020. The study will achieve this through the following objectives: (i) analysing the changes in LULC over the last thirty years; (ii) estimating the multi-temporal changes in NDVI, NDBI, and LST; (iii) examining LST variation as it relates NDVI and NDBI. 
The study is structured into five sections: the first section discusses the theoretical background; the second section explains the satellite data and methods utilised; the third section analyses the decadal changes in LULC, and LST and the various spectral indices comprising NDVI and NDBI; the fourth section discusses the implications of land cover changes on the urban climate; finally, the fifth section presents the study's conclusion.

\section{Research Data and Methods}

\subsection{Study Area: Kano Metropolis, Nigeria}

Kano Metropolis is located between latitudes $11^{\circ} 51^{\prime}$ to $12^{\circ} 08^{\prime}$ North and longitudes $8^{\circ} 25^{\prime}$ to $8^{\circ} 39^{\prime}$ East at an average altitude of approximately $472 \mathrm{~m}$ above sea level [43]. It is situated centrally in Nigeria's Northern region, about 900 kilometres from the edge of the Sahara desert and approximately 1140 kilometres away from the Atlantic Ocean within the Sudano-Sahelian Ecological Zone (SSEZ) of Nigeria [44]. The metropolis comprises eight Local Government Areas, as shown in Figure 1. The city's climatic condition is characterised as a tropical wet and dry savannah, coded 'Aw' according to Koppen's climatic classification. The city's seasonal changes occur between the wet and dry tropical air masses, referred to as Inter-Tropical Discontinuity (ITD), which results in two distinctive seasons [45]. The wet season often begins in June and ends around September annually, while the dry season typically commences in October and ends around May. As such, the climatic features of the city are similar to West Africa's savannah region. The mean annual temperature and rainfall data of the study area were obtained from the Automated Weather Observation Station (AWOS) of the Nigerian Metrological Agency (Table A1). The data indicated the yearly mean temperature to be between $26{ }^{\circ} \mathrm{C}$ to $28{ }^{\circ} \mathrm{C}$ for the study period. The vegetation is categorised under the Sahel, Sudan, and Guinea savannah types due to the natural surroundings and human activities [46]. Kano has a vast amount of fertile agricultural land that supports numerous food and cash crops such as millet, rice, sorghum, wheat, cowpeas, groundnut, and other vegetables. The metropolis is one of Nigeria's fastest-growing urban centres and has continuously attracted population due to the city's commercial and agricultural activities.

\subsection{Satellite Data}

The study was conducted using Landsat data, an archive containing satellite images of continuous earth observation. Images from four different epochs were acquired freely from the earth explorer portal (https: / / earthexplorer.usgs.gov / accessed on 5 June 2021) of the United States Geological Survey (USGS) using a decadal interval, i.e., 1990, 2000, 2010, and 2020. However, the unavailability of the satellite image for 1990 led to the study utilizing the subsequent year's image, i.e., 1991. The study considered ten year intervals due to the considerable growth and expansion of Nigeria's urban centres over the study period [47]. The images were obtained from Landsat 5 TM, Landsat 7 ETM+, and Landsat 8 OLI using Path 188, Row 52. Cloud-free images were downloaded, with a high spatial resolution of $30 \times 30 \mathrm{~m}$ and a swath width of $185 \times 185 \mathrm{~km}$. The images were georeferenced to the Universal Transverse Mercator (UTM) projection zone $32 \mathrm{~N}$ based on the location of the study area according to the World Geodetic System 1984 (WGS84). In the image pre-processing operations, multispectral bands of the various satellite images were stacked and clipped into the boundary of the study area. The specifications of the datasets used are presented in Table 1 . In addition, Table 2 presents the spectral bands used to retrieve the study's land surface temperature. 


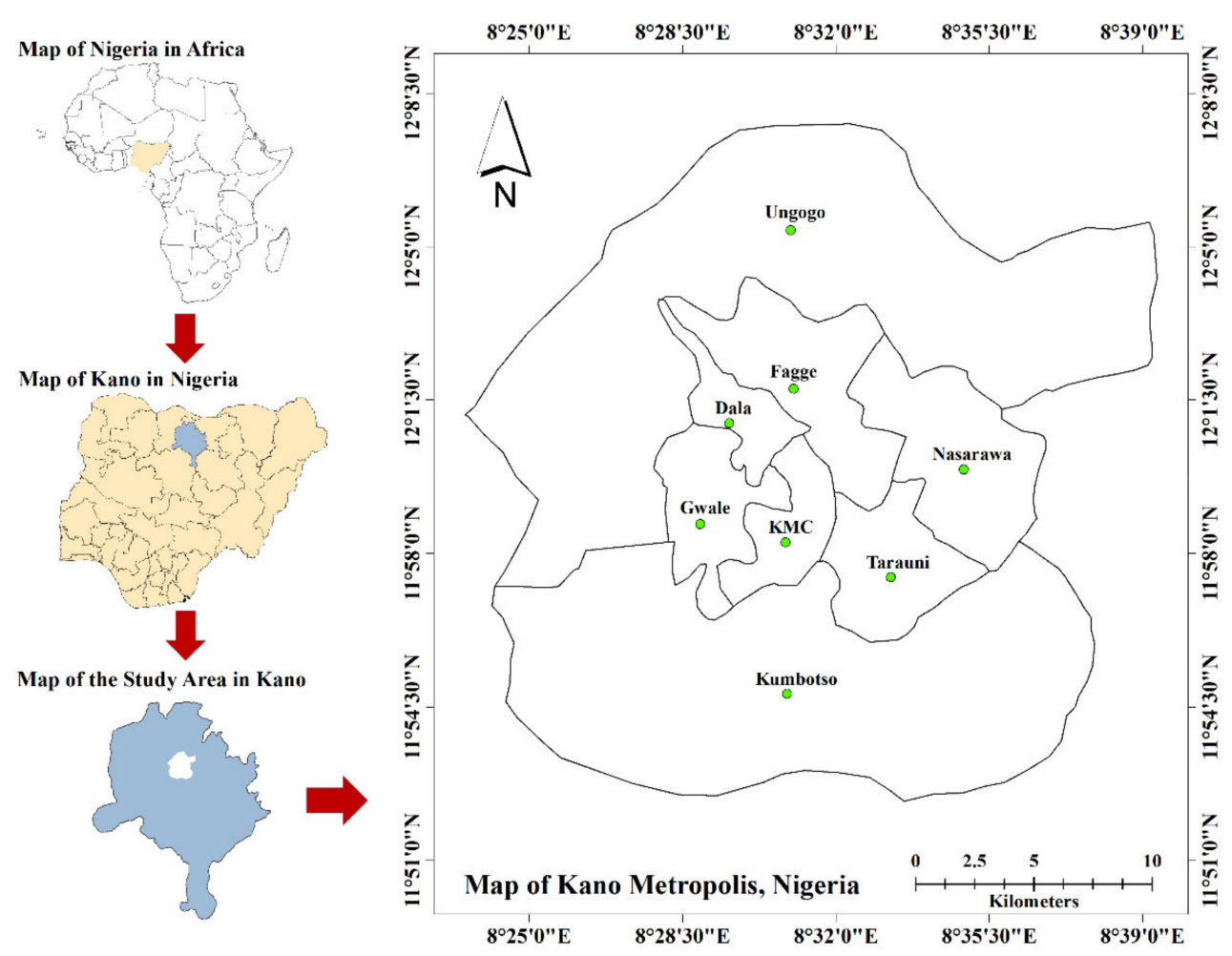

Figure 1. The study area (Kano Metropolis, Nigeria).

Table 1. Satellite Dataset used in the study.

\begin{tabular}{|c|c|c|c|c|c|c|c|c|}
\hline Acquisition Date & $\begin{array}{c}\text { Satellite } \\
\text { Name }\end{array}$ & $\begin{array}{l}\text { Sensor } \\
\text { Type }\end{array}$ & $\begin{array}{l}\text { Path/ } \\
\text { Row }\end{array}$ & $\begin{array}{l}\text { Cloud } \\
\text { Cover }\end{array}$ & $\begin{array}{c}\text { Time } \\
\text { (GMT) }\end{array}$ & No. of Bands & $\begin{array}{c}\text { Sun } \\
\text { Elevation }\end{array}$ & $\begin{array}{c}\text { Sun } \\
\text { Azimuth }\end{array}$ \\
\hline 7 January 1991 & Landsat 4 & TM & $188 / 052$ & 0.00 & 09:07:30 & 7 & 41.2293 & 134.1903 \\
\hline 4 March 2000 & Landsat 7 & ETM & $188 / 052$ & 0.00 & 09:35:35 & 8 & 55.2275 & 119.3095 \\
\hline 28 February 2010 & Landsat 7 & ETM & $188 / 052$ & 0.00 & 09:35:00 & 8 & 53.9963 & 121.4230 \\
\hline 16 February 2020 & Landsat 8 & OLI/TIRS & $188 / 052$ & 0.21 & $09: 42: 58$ & 11 & 52.7192 & 129.2164 \\
\hline
\end{tabular}

\subsection{Methods}

The methodology adopted involved three main procedures: image pre-processing (i.e., radiometric and atmospheric correction, layer stacking, and composite band selection,), image classification, and accuracy assessment. The processes were carried out using ENVI 5.3 image-processing software. A change detection analysis involving deriving the decadal LULC maps and a change analysis was also executed using ArcMap 10.7.1 software. The NDVI, NDBI, and LST maps of the study area were further retrieved to analyse the influence of urban expansion and LULC changes on urban climate. Finally, the implications of the study's results were highlighted. 
Table 2. Spectral information of satellite images.

\begin{tabular}{|c|c|c|c|}
\hline \multicolumn{4}{|c|}{ i. Landsat 5 TM Spectral Bands } \\
\hline Band Number & Band Name & Spatial Resolution (m) & Spectral Range $(\mu \mathrm{m})$ \\
\hline 1 & Blue & $30 \mathrm{~m}$ & $0.45-0.52$ \\
\hline 2 & Green & $30 \mathrm{~m}$ & $0.52-0.60$ \\
\hline 3 & Red & $30 \mathrm{~m}$ & $0.63-0.69$ \\
\hline 4 & NIR & $30 \mathrm{~m}$ & $0.76-0.90$ \\
\hline 5 & MIR & $30 \mathrm{~m}$ & $1.55-1.75$ \\
\hline 6 & TIR (Thermal) & $120 \mathrm{~m}$ & $10.41-12.50$ \\
\hline 7 & MIR & $30 \mathrm{~m}$ & $2.08-2.35$ \\
\hline \multicolumn{4}{|c|}{ ii. Landsat 7 ETM+ Spectral Bands } \\
\hline Band Number & Band Name & Spatial Resolution (m) & Spectral Range $(\mu \mathrm{m})$ \\
\hline 1 & Blue & $30 \mathrm{~m}$ & $0.441-0.514$ \\
\hline 2 & Green & $30 \mathrm{~m}$ & $0.519-0.601$ \\
\hline 3 & Red & $30 \mathrm{~m}$ & $0.631-0.692$ \\
\hline 4 & NIR & $30 \mathrm{~m}$ & $0.772-0.898$ \\
\hline 5 & SWIR & $30 \mathrm{~m}$ & $1.547-1.749$ \\
\hline 6 & TIR (Thermal) & $60 \mathrm{~m}$ & $10.31-12.36$ \\
\hline 7 & SWIR & $30 \mathrm{~m}$ & $2.064-2.345$ \\
\hline 8 & Pan & $15 \mathrm{~m}$ & $0.515-0.89$ \\
\hline \multicolumn{4}{|c|}{ iii. Landsat 8 OLI and TIRS Spectral Bands } \\
\hline Band Number & Band Name & Spatial Resolution (m) & Spectral Range $(\mu \mathrm{m})$ \\
\hline 1 & Coastal/Aerosol & $30 \mathrm{~m}$ & $0.435-0.451$ \\
\hline 2 & Blue & $30 \mathrm{~m}$ & $0.452-0.512$ \\
\hline 3 & Green & $30 \mathrm{~m}$ & $0.533-0.590$ \\
\hline 4 & Red & $30 \mathrm{~m}$ & $0.636-0.673$ \\
\hline 5 & NIR & $30 \mathrm{~m}$ & $0.851-0.879$ \\
\hline 6 & SWIR-1 & $30 \mathrm{~m}$ & $1.566-1.651$ \\
\hline 7 & SWIR-2 & $30 \mathrm{~m}$ & $2.107-2.294$ \\
\hline 8 & Pan & $15 \mathrm{~m}$ & $0.503-0.676$ \\
\hline 9 & Cirrus & $30 \mathrm{~m}$ & $1.363-1.384$ \\
\hline 10 & TIR-1 (Thermal) & $100 \mathrm{~m}$ & $10.60-11.19$ \\
\hline 11 & TIR-2 (Thermal) & $100 \mathrm{~m}$ & $11.50-12.51$ \\
\hline
\end{tabular}

Source: Landsat Data Users Handbook (https: / landsat.gsfc.nasa.gov / accessed on 11 November 2020).

\subsubsection{Classification of Satellite Images}

The radiometric and atmospheric corrected images were classified into four LULC categories using a false colour band combination, i.e., bands 7, 5, and 3 for Landsat TM and ETM+ and bands 7, 6, and 4 for Landsat OLI. These land cover classes comprise barren land, built-up areas, vegetation, and water bodies, as described in Table 3. The changes in LULC of an urban area can be attributed to various human activities and urbanization. This change can be obtained by classifying satellite data through remote sensing and GIS techniques that categorise image pixels into different LULC types. The classification of satellite images helps in producing thematic maps at a specified period. Several classification algorithms have been utilised previously by [48-52]. The spatial and quantitative information in this study was retrieved using the supervised classification algorithm. The Maximum Likelihood Classifier (MLC) was identified as the most prominent and robust classification technique that relies on pixel spectral information for accurate and precise land use/land classification [53,54]. Therefore, the study employed pixel-based maximum likelihood supervised classification to analyse the study area's land cover changes. The available satellite image for 1991 was used as the starting point, while 2020 was the final year, covering approximately 30 years. A minimum of 100 training samples was generated for each LULC category in order to train the Maximum Likelihood Classifier. The algorithm was applied to the datasets, and thematic LULC maps were produced for 1991, 
2000, 2010, and 2020. Post-Classification Comparison (PCC) was carried out using the procedures described in the literature for determining the quantitative changes in the individual land-use/land cover categories [55-57].

Table 3. Description of the study's LULC classes.

\begin{tabular}{|c|c|c|}
\hline S/No & $\begin{array}{c}\text { LULC } \\
\text { Classes }\end{array}$ & Description \\
\hline 1. & Barren land & $\begin{array}{c}\text { Mainly comprises gravel pits, construction sites, and other degraded soils that are not fertile for } \\
\text { vegetation growth. }\end{array}$ \\
\hline 2. & Built-up areas & $\begin{array}{c}\text { Includes areas dominated by human settlements containing residential, commercial, industrial, and } \\
\text { other infrastructural facilities. }\end{array}$ \\
\hline 3. & Vegetation & $\begin{array}{c}\text { Includes areas comprising grasses, low vegetated lands, trees, scrublands, and agricultural land } \\
\text { having food and cash crops. }\end{array}$ \\
\hline 4. & Waterbodies & Comprises rivers, streams, lakes, reservoirs, and ponds \\
\hline
\end{tabular}

\subsubsection{Accuracy Assessment of LULC Classification}

The accuracy of the classified images was assessed using the confusion/error matrix approach [58,59]. An equalised random sampling method was employed for an accurate and unbiased assessment. Fifty stratified random points were created for each LULC class in order to validate the study's classified land cover distribution. Historical Google Earth images were used for validating the actual ground truth conditions of the different land uses in the study area. The accuracy of the land cover classification was assessed using producer accuracy, user accuracy, overall accuracy, and the Kappa index of Agreement, i.e., Kappa coefficient. The producer's accuracy is calculated as the sum of the total classified pixels in the error/confusion matrix diagonals divided by the total classified pixels in the column category. User's accuracy is calculated by dividing the total sum of the correctly classified pixels in error matrix diagonals by the total sum of classified pixels in the row category. The overall accuracy is the ratio of the total correctly classified pixels by the total sum of pixels in the error matrix. As discussed in previous studies, the Kappa coefficient is the extent to which the reference data corresponds to the classified images [60]. The overall accuracy and kappa coefficient were computed in this study using Equations (1) and (2).

$$
\text { Overall Accuracy }(\mathrm{OA})=\frac{\sum_{\mathrm{i}}^{\mathrm{r}} x_{i i}}{x}
$$

where, $x_{i i}$ are the diagonal samples of the error matrix, $x$ is the total pixels in the error matrix

$$
\text { Kappa Coefficient }=\frac{\sum_{\mathrm{i}=1}^{\mathrm{r}} x_{i i}-\sum_{\mathrm{i}=1}^{\mathrm{r}} x_{i+} x_{+1}}{n^{2}-\sum_{\mathrm{i}=1}^{\mathrm{r}} x_{i+} x_{+1}}
$$

where $\mathrm{r}$ is the number of rows in the error matrix, $x_{i i}$ are the observed number in row $i$ and column $i, x_{i+}$ and $x_{+1}$ are the marginal sum of row $i$ and column $i$, respectively, while $n$ is the total sum of pixels in the error matrix.

\subsubsection{Normalised Difference Vegetation Index (NDVI)}

The study employed the Normalised Difference Vegetation Index (NDVI) as an indicator to evaluate the vegetation cover or amount of greenness in satellite images using the red and near-infrared bands [61]. The NDVI usually varies between -1 and 1 . Negative values of NDVI signify non-vegetated, while positive values of NDVI represent areas having vegetation cover [62]. The standard formula for retrieving NDVI was utilised in estimating the study area's vegetational cover, and was computed using Equation (3) [63].

$$
\mathrm{NDVI}=\frac{(\mathrm{NIR}-\mathrm{RED})}{(\mathrm{NIR}+\mathrm{RED})}
$$


where NIR is the Near-Infrared Band (i.e., $0.76-0.90 \mu \mathrm{m}$ for Landsat TM, $0.772-0.898 \mu \mathrm{m}$ for Landsat ETM+ and 0.851-0.879 $\mu \mathrm{m}$ for Landsat OLI) and RED is the Red Band (i.e., 0.63-0.69 $\mu \mathrm{m}$ for Landsat TM, 0.631-0.692 $\mu \mathrm{m}$ for Landsat ETM+ and 0.636-0.673 $\mu \mathrm{m}$ for Landsat OLI). The NDVI value usually ranges from -1 to 1 . Low NDVI values signify non-vegetated areas, while high NDVI values represent dense vegetation.

\subsubsection{Normalized Difference Built-Up Index (NDBI)}

The Normalized Difference Built-up Index (NDBI) extracted the study's built-up areas, as employed in previous literature [64-66]. The NDBI was calculated using Equation (4).

$$
\mathrm{NDBI}=\frac{(\mathrm{MIR}-\mathrm{NIR})}{(\mathrm{MIR}+\mathrm{NIR})}
$$

where MIR is the Mid-Infrared Band (i.e., 1.55-1.75 $\mu \mathrm{m}$ for Landsat TM, 1.547-1.749 $\mu \mathrm{m}$ for Landsat ETM+ and 1.566-1.651 $\mu \mathrm{m}$ for Landsat OLI) and NIR is the Near-Infrared Band of Landsat TM $(0.76-0.90 \mu \mathrm{m})$, Landsat ETM+ $(0.772-0.898 \mu \mathrm{m})$ and Landsat OLI $(0.851-0.879 \mu \mathrm{m})$. The NDBI values range between -1 and 1 , where negative values signify waterbodies and positive values represent built-up/developed urban areas. Low NDBI values usually denote vegetation cover.

\subsubsection{Land Surface Temperature (LST)}

The study employed the thermal infrared bands of the different satellite images as established by Qin, et al. [67] to derive LST. The earth's surface radiation was observed using spectral reflectance ranging between 10.4 to $12.5 \mu \mathrm{m}$. The LST retrieval procedures involved four major steps [68,69].

\section{- Conversion of Digital Number values to Spectral Radiance}

The digital numbers, i.e., the satellite images' pixel values, were converted using the scaling method into spectral radiance as presented in Equation (5) for Landsat TM and ETM+ and Equation (6) for Landsat OLI.

$$
\begin{gathered}
L_{\lambda}=\left(\frac{L_{\text {Max. } . \lambda}-L_{\text {Min. } . \lambda}}{Q_{\text {Cal.Max }}-Q_{\text {Cal.Min }}}\right) \times\left(Q_{\text {Cal }}-Q_{\text {Cal.Min }}\right)+L_{\text {Min } . \lambda} \\
L_{\lambda}=M_{L} \times Q_{\text {Cal }}+\Delta_{L}
\end{gathered}
$$

where $L_{\lambda}=$ Spectral radiance $\left(\mathrm{w} \cdot \mathrm{sr}^{-1} \cdot \mathrm{m}^{-3}\right), L_{\text {Max. } \lambda}=$ Spectral radiance scaled to $Q_{\text {Cal.Max }}$ i.e., DN value $255, L_{\text {Min. } \lambda}=$ Spectral radiance scaled to $Q_{\text {Cal.Min }}$ i.e., $D N$ value $1, Q_{\text {Cal }}=$ Pixel values of satellite images (Digital Number), $Q_{\text {Cal.Max }}=$ Quantitized and calibrated maximum pixel value that corresponds to $L_{\text {Max. } \lambda}, Q_{\text {Cal.Min }}=$ Quantitized and calibrated minimum pixel value that corresponds to $L_{M i n} \lambda, M_{L}=$ Multiplicative scaling factor for the radiance of the specific spectral band (x) obtained from the metadata of the dataset (i.e., RADIANCE_MULT_BAND_x), and $\Delta_{L}=$ additive scaling factor for the radiance of the spectral band $(x)$ retrieved from the image's dataset (i.e., RADIANCE_ADD_BAND_x).

- $\quad$ Conversion of Spectral Radiance to Temperature (in Kelvin)

This step involves the conversion of spectral radiance into brightness temperature $\left(T_{B}\right)$ i.e., the top of the atmosphere (TOA), using Planck's Radiance Function. The brightness temperature $\left(T_{B}\right)$ also corresponds to the apparent surface temperature reaching the satellite sensor, and is calculated using the standard formula presented in Equation (7) [69]:

$$
\mathrm{T}_{\mathrm{B}}=\frac{\mathrm{K}_{2}}{\log \left(\frac{\mathrm{K}_{1}}{L_{\lambda}}+1\right)}
$$

where $\mathrm{K}_{1}$ and $\mathrm{K}_{2}=$ Calibration constants of thermal bands obtained from the image's metadata (Table 4$), L_{\lambda}=$ Spectral radiance $\left(\mathrm{w} \cdot \mathrm{sr}^{-1} \cdot \mathrm{m}^{-3}\right)$, and $\mathrm{T}_{\mathrm{B}}=$ Brightness Temperature (in Kelvin). 
Table 4. Landsat Thermal Band Calibration Constant.

\begin{tabular}{ccccc}
\hline S/No. & Satellite & Thermal Band & $\mathbf{K}_{\mathbf{1}} \mathbf{( W \cdot \mathbf { m } ^ { - \mathbf { 2 } } \cdot \mathbf { s r } ^ { \mathbf { - 1 } } \cdot \boldsymbol { \mu } \mathbf { m } ^ { - \mathbf { 1 } } )}$ & $\mathbf{K}_{\mathbf{2}}$ (Kelvin) \\
\hline 1. & Landsat 4 TM & Band 6 & 671.62 & 1284.30 \\
2. & Landsat 7 ETM+ & Band 6 & 666.09 & 1282.71 \\
3. & Landsat 8 OLI & Band 10 & 774.89 & 1321.08 \\
4. & Landsat 8 OLI & Band 11 & 480.89 & 1201.14 \\
\hline
\end{tabular}

- $\quad$ Conversion of Temperature (in Kelvin) to Degrees Celsius

This step involves converting surface temperature from degrees Kelvin $\left({ }^{\circ} \mathrm{K}\right)$ to degrees Celsius $\left({ }^{\circ} \mathrm{C}\right)$ using Equation (8).

$$
\mathrm{T}_{\mathrm{B}\left({ }^{\circ} \mathrm{C}\right)}=\mathrm{T}_{\mathrm{B}(\text { in Kelvin })}-273.15
$$

- $\quad$ Estimation of Land Surface Temperature (LST)

The study's LST was computed from the at-sensor brightness temperature using Equation (9):

$$
\operatorname{LST}_{\left({ }^{\circ} \mathrm{C}\right)}=\frac{\mathrm{T}_{\mathrm{B}}}{1+\left(\lambda \times \frac{\mathrm{T}_{\mathrm{B}}}{\rho}\right) \times \operatorname{Ln}(\varepsilon)}
$$

where, $\mathrm{T}_{\mathrm{B}}=$ at sensor brightness Temperature, $\lambda=$ emitted radiance wavelength $(11.5 \mu \mathrm{m})$,

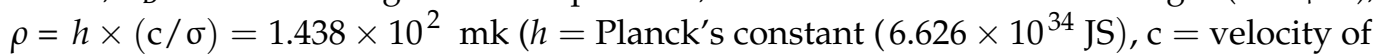
light $\left(2.998 \times 10^{8} \mathrm{~m} / \mathrm{s}\right)$ and $\sigma=$ Boltzmann constant $\left(1.38 \times 10^{23} \mathrm{~J} / \mathrm{k}\right)$ and $\varepsilon$ is the surface emissivity calculated using Equation (10).

$$
\text { Surface emissivity }(\varepsilon)=0.004(\mathrm{Pv})+0.986
$$

where Pv is the proportion of vegetation retrieved using Equation (11).

$$
P v=\left[\frac{\left(\mathrm{NDVI}-\mathrm{NDVI}_{\min }\right)}{\left(\mathrm{NDVI}_{\max }-\mathrm{NDVI}_{\min }\right)}\right]^{2}
$$

where NDVI = Normalised Difference Vegetation Index, $\mathrm{NDVI}_{\min }$ is the minimum value of NDVI, and $\mathrm{NDVI}_{\max }$ is the maximum value of NDVI.

\subsubsection{Correlation and Regression Analyses}

A linear correlation (Pearson) analysis [70] was then performed in order to evaluate the correlation between the LST component of urban climate and spectral indices that include NDVI and NDBI. The LST values for the four time epochs under consideration were extracted from each year's image pixel at the individual points of the various spectral indices. These points were then used as input data for the study's model, and the relationship between LST and land cover change dynamics was analysed. The methodological procedures adopted for achieving the study's objectives are summarised in Figure 2, which shows the flowchart of the study. 


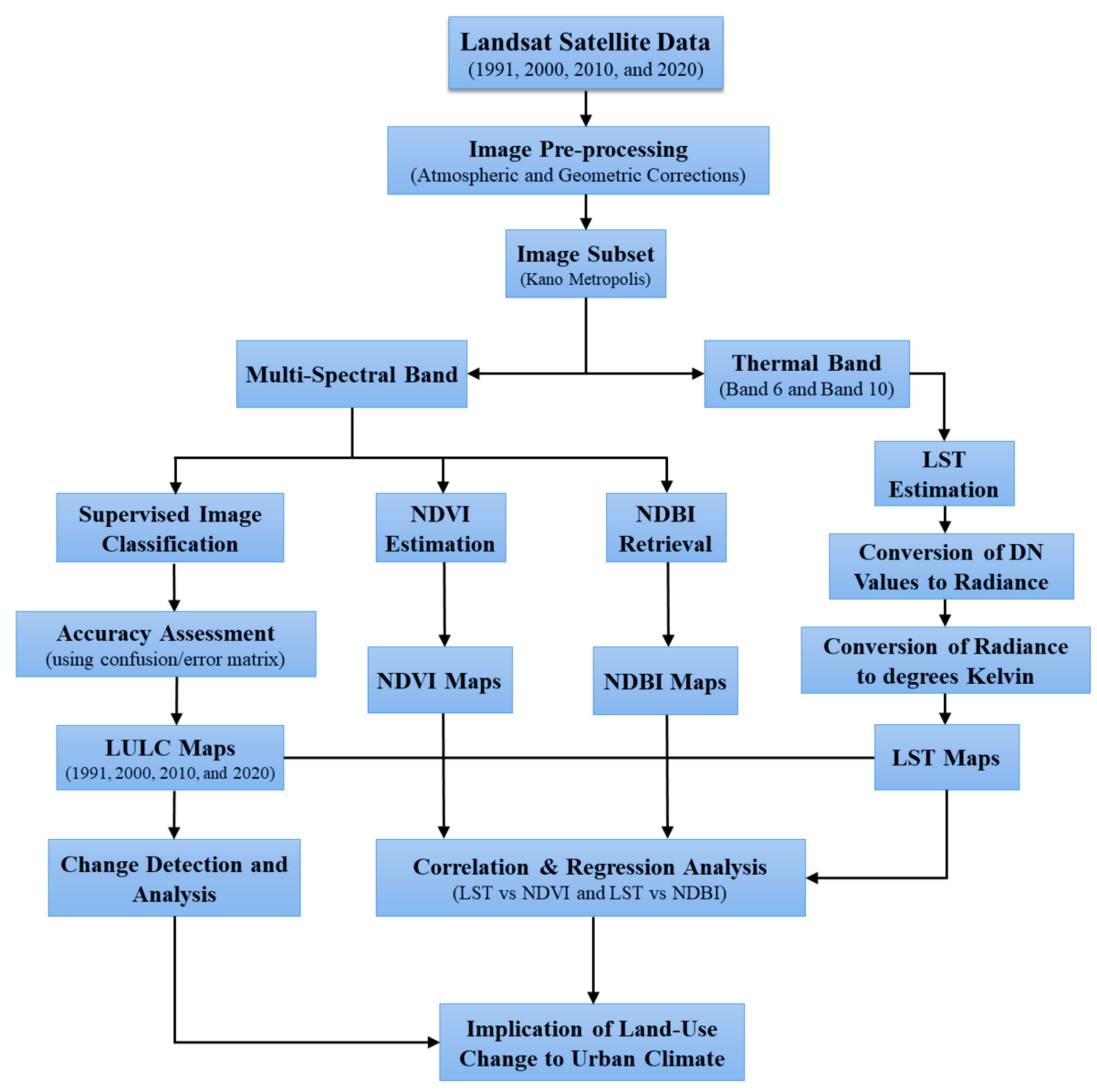

Figure 2. Methodological flowchart of the study.

\section{Results and Discussion}

\subsection{Spatial Distribution of LULC Classes, Decadal Changes and Transitions}

The distribution of land uses extracted using the supervised classification algorithm indicates the land features during the different periods under the study to include barren lands, built-up areas, vegetation, and water bodies, as illustrated in Figure 3. The results presented in Table 5 and Figure 4 show the LULC classes and their statistical distribution. In 1991, barren land occupied the most extensive area, having approximately $413.47 \mathrm{sq} . \mathrm{km}$ $(71.88 \%)$, followed by built-up areas with an area of $66.16 \mathrm{sq} . \mathrm{km}(11.50 \%)$ and closely vegetated lands having an area of $63.68 \mathrm{sq} . \mathrm{km}(11.07 \%)$, respectively. Water bodies covered 31.93 sq. km, representing $5.55 \%$ of the city's landmass. In 2000, barren land covered approximately $71.32 \%$ of the study area's landmass, followed by built-up areas, vegetation, and water bodies having $16.78 \%, 9.77 \%$, and $2.33 \%$, respectively. This trend of LULC pattern continued from 2010 to 2020 with a significant increase in built-up areas, from $139.26 \mathrm{sq}$. $\mathrm{km}(24.21 \%)$ to $218.71 \mathrm{sq}$. $\mathrm{km}(38.02 \%)$ and a decrease in barren land, from 355.78 sq. $\mathrm{km}(61.85 \%)$ to 240.89 sq. $\mathrm{km}(41.88 \%)$. Vegetation showed an inverse trend during this period, increasing from 74.78 sq. $\mathrm{km}(13.00 \%)$ in 2010 to $110.25 \mathrm{sq} . \mathrm{km}(19.17 \%)$ in 2020. This increase can be associated with the enormous investment in agricultural activities over the last ten years, which contributed significantly to the alteration of land use. 

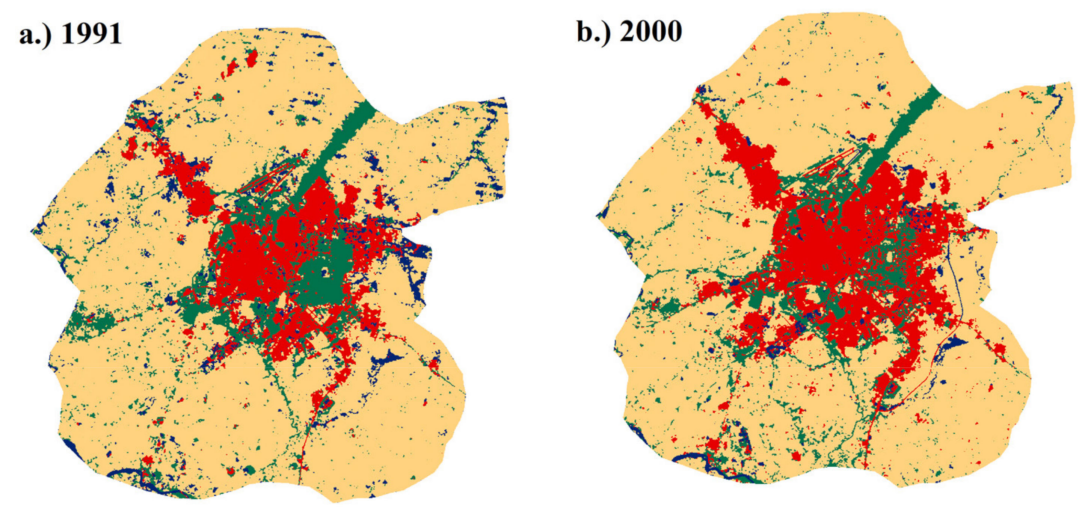

c.) 2010

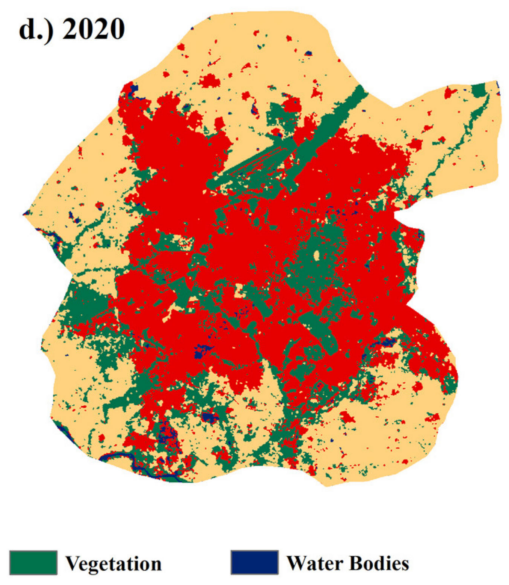

Figure 3. LULC Map for the years (a) 1991, (b) 2000, (c) 2010, and (d) 2020.

Table 5. Statistical Data of the LULC classes.

\begin{tabular}{lcccccccc}
\hline \multirow{2}{*}{ LULC Classes } & \multicolumn{2}{c}{ 1991 Area } & \multicolumn{2}{c}{ 2000 Area } & \multicolumn{2}{c}{ 2010 Area } & \multicolumn{2}{c}{ 2020 Area } \\
\cline { 2 - 9 } & Sq.km & Percent & Sq.km & Percent & Sq.km & Percent & Sq.km & Percent \\
\hline Barren Land & 413.47 & 71.88 & 410.26 & 71.32 & 355.78 & 61.85 & 240.89 & 41.88 \\
Built-up Areas & 66.16 & 11.50 & 96.51 & 16.78 & 139.26 & 24.21 & 218.71 & 38.02 \\
Vegetation & 63.68 & 11.07 & 56.23 & 9.77 & 74.78 & 13.00 & 110.25 & 19.17 \\
Water Bodies & 31.93 & 5.55 & 12.24 & 2.13 & 5.42 & 0.94 & 5.38 & 0.93 \\
\hline Total & $\mathbf{5 7 5 . 2 4}$ & $\mathbf{1 0 0 . 0 0}$ & $\mathbf{5 7 5 . 2 4}$ & $\mathbf{1 0 0 . 0 0}$ & $\mathbf{5 7 5 . 2 4}$ & $\mathbf{1 0 0 . 0 0}$ & $\mathbf{5 7 5 . 2 4}$ & $\mathbf{1 0 0 . 0 0}$ \\
\hline
\end{tabular}

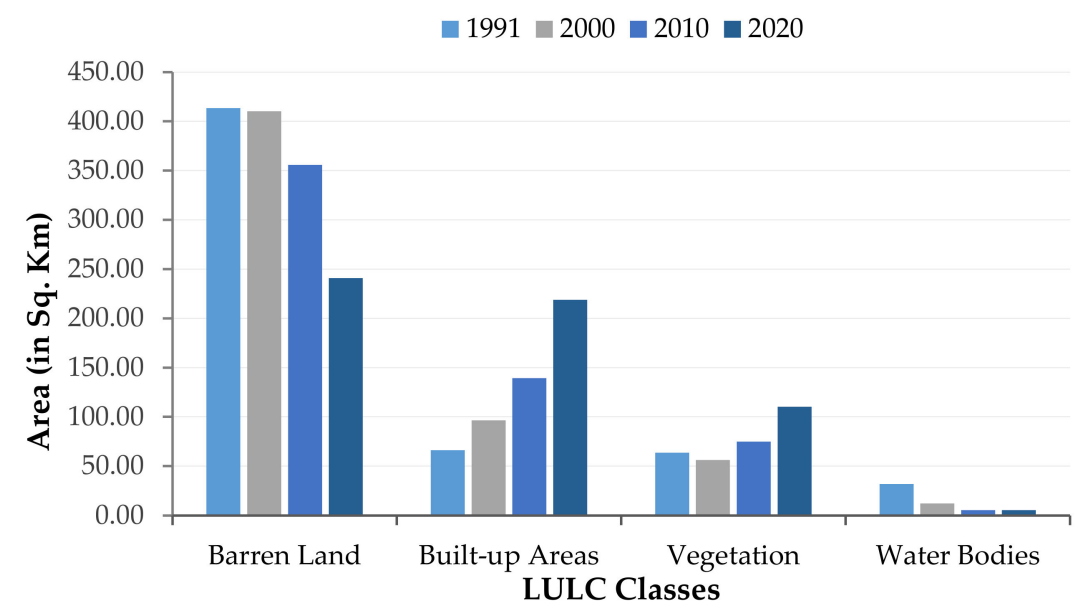

Figure 4. Graphical distribution of land uses for the years 1991, 2000, 2010 and 2020. 
The results of the decadal changes in land uses are shown in Table 6. In addition, the losses and gains of the four LULC classes, alongside their net contributions to the expansion of built-up areas, are illustrated in Figure 5.

Table 6. Decadal Net Changes of LULC classes.

\begin{tabular}{|c|c|c|c|c|c|c|c|c|}
\hline \multirow{2}{*}{$\begin{array}{l}\text { LULC } \\
\text { Classes }\end{array}$} & \multicolumn{2}{|c|}{ 1991-2000 } & \multicolumn{2}{|c|}{ 2000-2010 } & \multicolumn{2}{|c|}{ 2010-2020 } & \multicolumn{2}{|c|}{ 1991-2020 } \\
\hline & $\begin{array}{c}\text { Area } \\
\left(\mathbf{k m}^{2}\right)\end{array}$ & $\%$ Change & $\begin{array}{c}\text { Area } \\
\left(\mathrm{km}^{2}\right)\end{array}$ & $\%$ Change & $\begin{array}{c}\text { Area } \\
\left(\mathrm{km}^{2}\right)\end{array}$ & $\%$ Change & $\begin{array}{c}\text { Area } \\
\left(\mathrm{km}^{2}\right)\end{array}$ & $\%$ Change \\
\hline Barren Land & -3.20 & -0.78 & -54.49 & -15.31 & -114.89 & -47.69 & -172.58 & -71.64 \\
\hline Built-up Areas & 30.34 & 31.44 & 42.76 & 30.70 & 79.45 & 36.33 & 152.55 & 69.75 \\
\hline Vegetation & -7.45 & -13.24 & 18.55 & 24.81 & 35.47 & 32.17 & 46.58 & 42.25 \\
\hline Water Bodies & -19.69 & -160.89 & -6.82 & -126.05 & -0.04 & -0.67 & -26.55 & -493.67 \\
\hline
\end{tabular}

a.) Losses and Gains between 1991 and 2000 (Period 1)

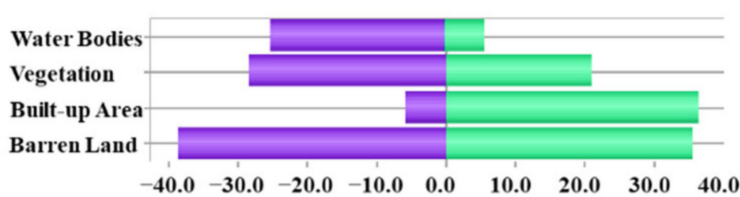

b.) Losses and Gains between 2000 and 2010 (Period 2)

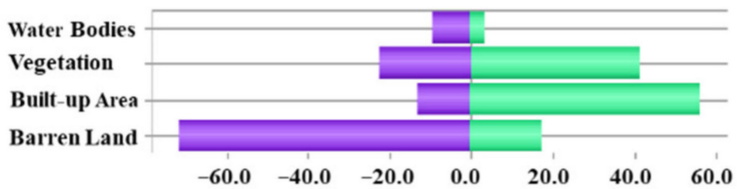

c.) Losses and Gains between 2010 and $2020($ Period 3)

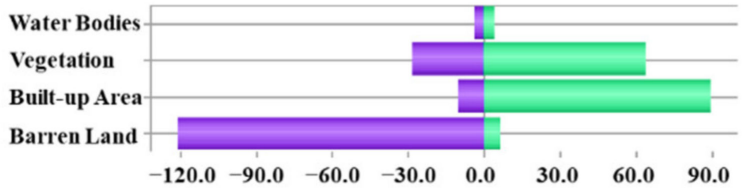

a.) Contributions to Net Change in Built-up Area (1991-2000)

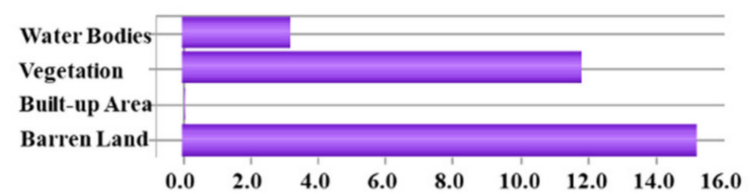

b.) Contributions to Net Change in Built-up Area (2000-2010)

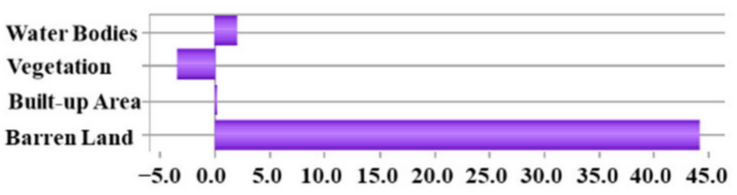

c.) Contributions to Net Change in Built-up Area (2010-2020)

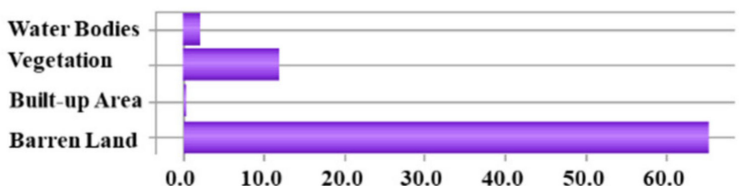

Figure 5. Net changes of the various LULC classes and their contributions to built-up areas (in sq.km) during the different study periods.

The study results reveal that during period one, between 1991-2000, the city's water bodies saw the most significant net change, -19.69 sq. $\mathrm{km}(-160.89 \%)$, which comprises an area loss of $-25.38 \mathrm{sq}$. $\mathrm{km}(-79.49 \%)$ and a gain of $5.69 \mathrm{sq}$. $\mathrm{km}(46.48 \%)$. Vegetated land saw a net change of $-7.45 \mathrm{sq} . \mathrm{km}(-13.24 \%)$, which comprises an area loss of $-28.4 \mathrm{sq} . \mathrm{km}$ $(-44.67 \%)$ and a gain of $21.00 \mathrm{sq} . \mathrm{km}(37.34 \%)$. Built-up areas saw a net change of 30.34 sq. $\mathrm{km}(31.44 \%)$, which comprises an area loss of -5.99 sq. $\mathrm{km}(-9.05 \%)$ and a gain of 36.33 sq. $\mathrm{km}(37.65 \%)$. Barren land witnessed a net change of $-3.20 \mathrm{sq} . \mathrm{km}(-0.78 \%)$, which comprises an area loss of $38.78 \mathrm{sq}$. $\mathrm{km}(9.38 \%)$ and a gain of $35.57 \mathrm{sq} . \mathrm{km}(8.67 \%)$. These findings suggest the built-up areas have experienced the most significant increase among the four land uses between 1991 and 2000, with barren land, vegetation, and water bodies contributing $15.26 \mathrm{sq}$. km, $11.84 \mathrm{sq}$. km, and 3.24 sq. km, respectively.

During period two, between 2000 and 2010, water bodies observed a net change of -6.82 sq. $\mathrm{km}(-126.05 \%)$, comprising of an area loss of $-10.03 \mathrm{sq}$. $\mathrm{km}(-81.95 \%)$ and a gain of 3.20 sq. $\mathrm{km}(59.19 \%)$. Vegetated land witnessed a decline of $-22.48 \mathrm{sq} . \mathrm{km}$ $(-39.98 \%)$ and an increase of 41.03 sq. $\mathrm{km}(54.87 \%)$, a net increase of $18.55 \mathrm{sq} . \mathrm{km}(24.81 \%)$. The city's built-up areas witnessed a net increase of 42.76 sq. km (30.70\%), comprising 
an area decrease of -13.46 sq. $\mathrm{km}(-13.95 \%)$ and an increase of 56.22 sq. $\mathrm{km}(40.37 \%)$. Barren land experienced a net change of -54.49 sq. $\mathrm{km}(-15.31 \%)$, comprising an area loss of -71.69 sq. $\mathrm{km}(-17.47 \%)$ and a gain of $17.21 \mathrm{sq} . \mathrm{km}(4.84 \%)$. The trend of the city's built-up areas witnessing the most substantial growth continued during this period, with barren lands and water bodies declining. This led to the increase in built-up areas and the transformation of $44.06 \mathrm{sq}$. $\mathrm{km}$ of barren land and $2.21 \mathrm{sq}$. $\mathrm{km}$ of water bodies into urban areas.

In the third period, the city's water bodies observed a slight net change of $-0.04 \mathrm{sq} . \mathrm{km}$ $(-0.67 \%)$, comprising a decrease of $-4.15 \mathrm{sq} . \mathrm{km}(-76.65 \%)$ and an increase of $4.11 \mathrm{sq} . \mathrm{km}$ $(76.49 \%)$. Vegetated land saw a loss of $-28.52 \mathrm{sq} . \mathrm{km}(-38.14 \%)$ and a gain of $63.99 \mathrm{sq} . \mathrm{km}$ $(58.04 \%)$, resulting in a net increase of $35.47 \mathrm{sq} . \mathrm{km}(32.17 \%)$. The built-up areas saw a net increase of 79.45 sq. $\mathrm{km}(36.33 \%)$, comprising an area decline of -10.02 sq. $\mathrm{km}(-7.20 \%)$ and a gain of $89.47 \mathrm{sq} . \mathrm{km}(40.91 \%)$. Barren land witnessed a net change of $-114.89 \mathrm{sq} . \mathrm{km}$ $(-47.69 \%)$, comprising an area loss of -120.91 sq. $\mathrm{km}(-33.98 \%)$ and a gain of $6.02 \mathrm{sq} . \mathrm{km}$ (2.50\%). Between 2010 and 2020, Barren land, vegetation, and water bodies contributed 65.14 sq. $\mathrm{km}, 12.14 \mathrm{sq}$. km, and $2.18 \mathrm{sq}$. km, respectively, to the growth and expansion of the city's built-up area.

The land cover distribution between 1991 and 2020 showed various losses and gains during the study period, as illustrated in Figure 6. It indicates a $-190.93 \mathrm{sq} . \mathrm{km}(-46.18 \%)$ loss in barren land and a gain of 18.36 sq.km (7.62\%). The city's built-up area lost -6.52 sq. $\mathrm{km}(-9.86 \%)$ and gained $159.07 \mathrm{sq} . \mathrm{km}(72.73 \%)$. Vegetation saw a loss of -25.66 sq. $\mathrm{km}(-40.30 \%)$ and a gain of 72.24 sq. $\mathrm{km}(65.52 \%)$, while water bodies lost -29.50 sq. $\mathrm{km}(-92.40 \%)$ and gained 2.95 sq. km (54.85\%). Therefore, it is evident that builtup areas experienced the most significant increase from 1991 to 2020, having $152.55 \mathrm{sq}$. km urban growth. Barren land, vegetation, and water bodies contributed $126.99 \mathrm{sq} . \mathrm{km}$, $12.83 \mathrm{sq}$. km, and $12.73 \mathrm{sq}$. km, respectively, to this expansion of built-up areas between 1991 and 2020. This development is attributed to the city's rapid urbanization, and aligns with previous studies which highlight the environmental challenge of urban modification, i.e., increased land surface temperature due to LULC alterations $[40,61,66,71]$.

These results demonstrate the various transitions of land uses from one class to another, as presented in Figure 7. The most significant alteration is the transformation of approximately $128.51 \mathrm{sq}$. $\mathrm{km}$ of barren land into built-up areas. This alteration could be associated with the city's population growth, which has contributed to massive infrastructural, residential, commercial, and industrial development. In addition, the enormous investment in agricultural activities over the last 30 years in Kano Metropolis has contributed substantially to the conversion of $59.97 \mathrm{sq}$. $\mathrm{km}$ of barren land into vegetated areas with trees, shrubs, and agricultural land for the cultivation of various food and cash crops such as groundnuts, rice, millet, maize, sorghum, wheat, etc. Other transitions in land uses include the conversion of $17.69 \mathrm{sq}$. $\mathrm{km}$ of vegetation into built-up areas, the transformation of $12.90 \mathrm{sq}$. $\mathrm{km}$ of water bodies into impervious surfaces of these built-up areas, and the conversion of $9.17 \mathrm{sq}$. $\mathrm{km}$ of water bodies into barren lands.

\subsection{Accuracy Assessment of Land Uses}

The classified LULC maps were derived using the error/confusion matrix, as presented in Table 7. It shows the three accuracies and the Kappa coefficients for 1991, 2000, 2010, and 2020. Producer accuracy indicated the likelihood of reference image pixels being correctly classified. User accuracy measured the probability of the classified image pixels representing actual condition of the earth's surface [58,72]. An overall accuracy above $85 \%$ suggests a satisfactory land cover classification. In this study, producer and user accuracy improved for the different land uses, with the overall accuracy increasing from $88 \%$ in 1991 to $95 \%$ in 2020 , indicating a good LULC classification. The artifacts observed in the classified image of 1991 could be attributed to an image error that occurred during the overpassing of satellite. However, the results of the overall accuracies are all above satisfactory, implying that any such error could be neglected. The Kappa coefficients were 
also found to be 0.8137 in 1991, 0.8652 in 2000, 0.8891 in 2010, and 0.9190 in 2020, signifying good agreement between classified maps and the actual ground conditions.

a.) Losses and Gains in Barren Land

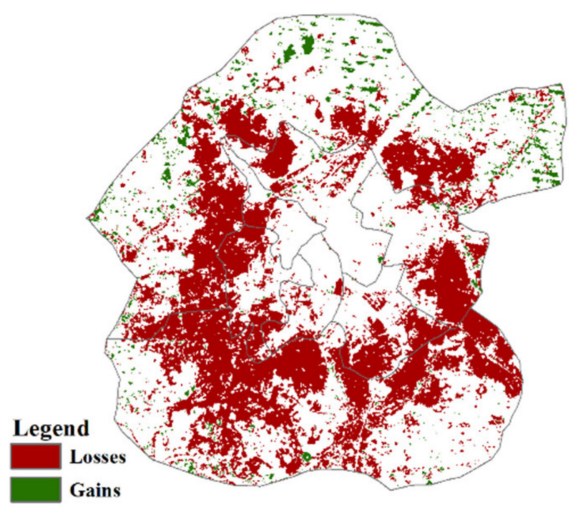

c.) Losses and Gains in Vegetation

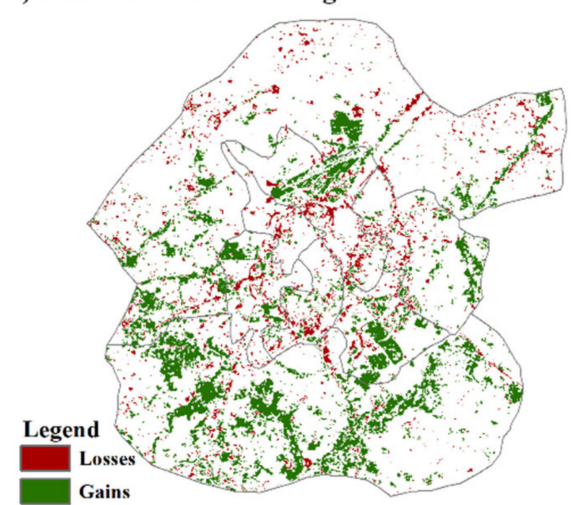

b.) Losses and Gains in Built-up Areas

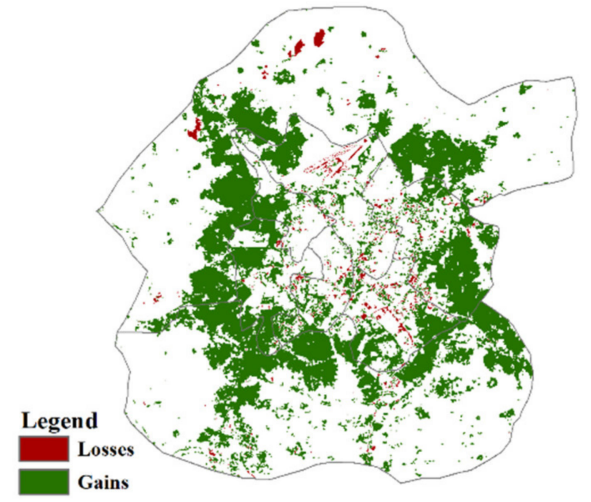

d.) Losses and Gains in Water Bodies

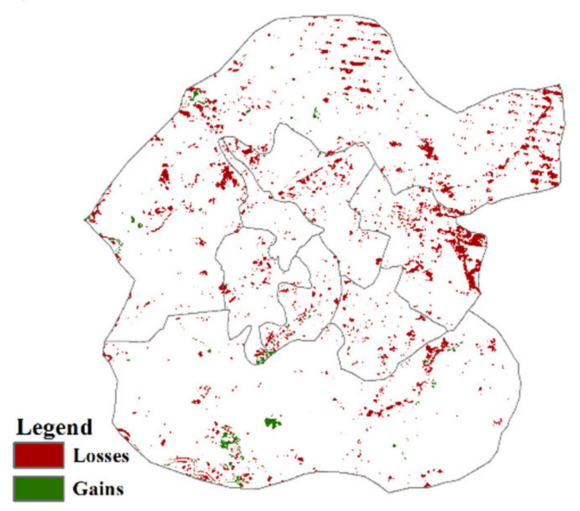

Figure 6. Losses and Gains in LULC classes from 1991-2020.

\section{Land Use/Land Cover Transistion}

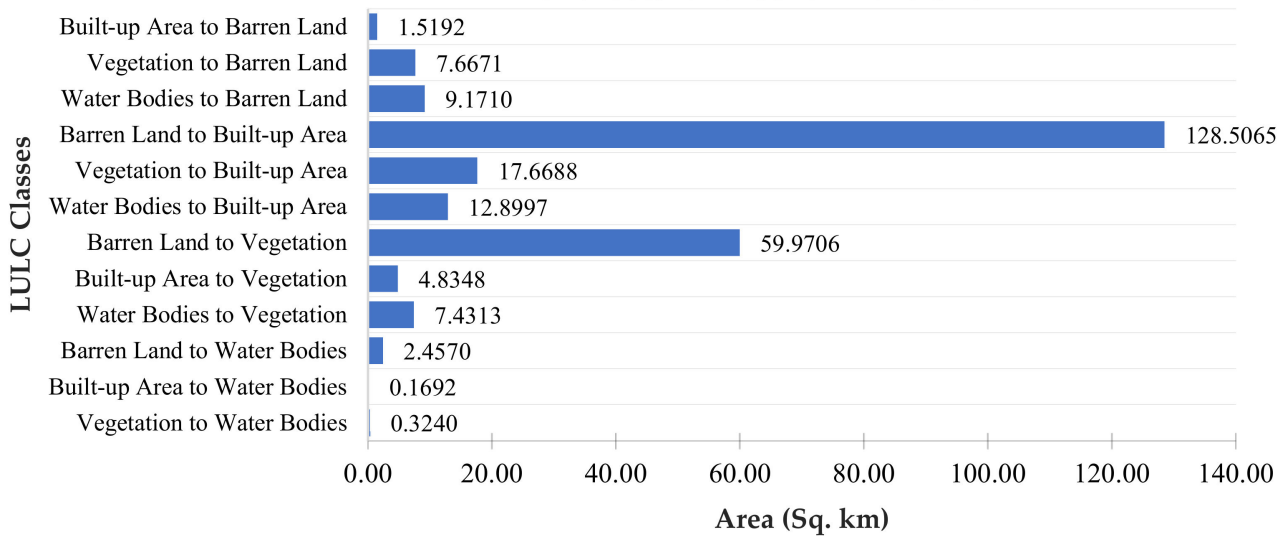

Figure 7. Land Use/Land Cover Transitions in Kano Metropolis, Nigeria (1991-2020). 
Table 7. Accuracy Assessment of classified LULC maps.

\begin{tabular}{|c|c|c|c|c|c|c|c|c|}
\hline \multirow{3}{*}{$\begin{array}{l}\text { LULC } \\
\text { Classes }\end{array}$} & \multicolumn{2}{|c|}{1991} & \multicolumn{2}{|c|}{2000} & \multicolumn{2}{|c|}{2010} & \multicolumn{2}{|c|}{2020} \\
\hline & Prod Ac. & User Ac. & Prod Ac. & User Ac. & Prod Ac. & User Ac. & Prod Ac. & User Ac. \\
\hline & \multicolumn{2}{|c|}{ Percent (\%) } & \multicolumn{2}{|c|}{ Percent (\%) } & \multicolumn{2}{|c|}{ Percent (\%) } & \multicolumn{2}{|c|}{ Percent (\%) } \\
\hline Barren Land & 90.93 & 92.14 & 92.20 & 97.27 & 99.81 & 98.80 & 99.82 & 96.15 \\
\hline Built-up Areas & 89.36 & 83.96 & 90.66 & 98.82 & 88.48 & 99.97 & 93.27 & 98.97 \\
\hline Vegetation & 79.28 & 89.77 & 91.85 & 65.63 & 97.87 & 59.77 & 94.84 & 80.83 \\
\hline Water Bodies & 77.91 & 87.58 & 91.85 & 67.81 & 98.04 & 38.61 & 92.25 & 96.75 \\
\hline Overall Accuracy & \multicolumn{2}{|c|}{$88.53 \%$} & \multicolumn{2}{|c|}{$91.71 \%$} & \multicolumn{2}{|c|}{$93.54 \%$} & \multicolumn{2}{|c|}{$95.24 \%$} \\
\hline Kappa Coefficient & \multicolumn{2}{|c|}{0.8137} & \multicolumn{2}{|c|}{0.8652} & \multicolumn{2}{|c|}{0.8891} & \multicolumn{2}{|c|}{0.9190} \\
\hline
\end{tabular}

\subsection{Urban Expansion of Kano Metropolis}

The built-up area development illustrated in Figure 8 indicates the study's urban expansion over the last 29 years. It shows an outward growth from the city's central core to the western, eastern, and southern parts of the metropolis, with the northern region having developed the least. Generally, the urban area witnessed expansion in all directions over the period between 1991 and 2020. The city's built-up area covered a landmass of approximately $66.16 \mathrm{sq} . \mathrm{km}$ in 1991, $96.51 \mathrm{sq} . \mathrm{km}$ in 2000, $139.26 \mathrm{sq} . \mathrm{km}$ in 2010, and $218.71 \mathrm{sq} . \mathrm{km}$ in 2020, respectively. Analysis of these results indicates that between 1991 and 2000, built-up area increased by approximately $30.34 \mathrm{sq} . \mathrm{km}$, an increase of $3.37 \mathrm{sq} . \mathrm{km}$ per annum. The city experienced a $42.76 \mathrm{sq}$. km increase in built-up areas between 2000 and 2010, resulting in $4.28 \mathrm{sq}$. km annual urban expansion. This further increased to $7.95 \mathrm{sq} . \mathrm{km}$ per annum between 2010 and 2020. These results clearly show that the yearly increase in built-up area from 2010-2020 is more than twice the annual urban growth from 1991-2000. Hence, these findings imply slow urbanization within the first decade (i.e., 1991-2000) compared to the last decade (i.e., 2010-2020). The main push and pull factors responsible for this growth are related to the city's commercial and agricultural activities.

\subsection{Normalised Difference Vegetation Index}

The NDVI maps derived using the satellite data of 1991-2020 are presented in Figure 9. The results reveal a mean NDVI value of approximately $0.01,-0.25,-0.06$, and 0.10 in 1991, 2000, 2010, and 2020, respectively. The study results indicate the NDVI values to be between -0.30 and +0.43 in 1991. The NDVI values changed to -0.55 and +0.13 in 2000, while in 2010, the minimum and maximum NDVI values were -0.46 and +0.30 . The study further witnessed an alteration of NDVI in 2020 with minimum and maximum values of -0.14 and +0.30 , respectively. Previous studies indicate that areas with higher NDVI values signify forest and vegetated lands having agricultural farms, while lower NDVI values represent built-up areas and other land uses such as barren land and water bodies $[61,73]$. The NDVI maps showed a substantial decrease in vegetation cover, with lower NDVI values from 1991 to 2020. Built-up areas showed lower NDVI values than other LULC classes during the study period. Therefore, the alteration of land uses may have influenced the city's vegetation cover. This aligns with a recent study that suggests a continuous decline in NDVI with increased urban expansion [40]. 


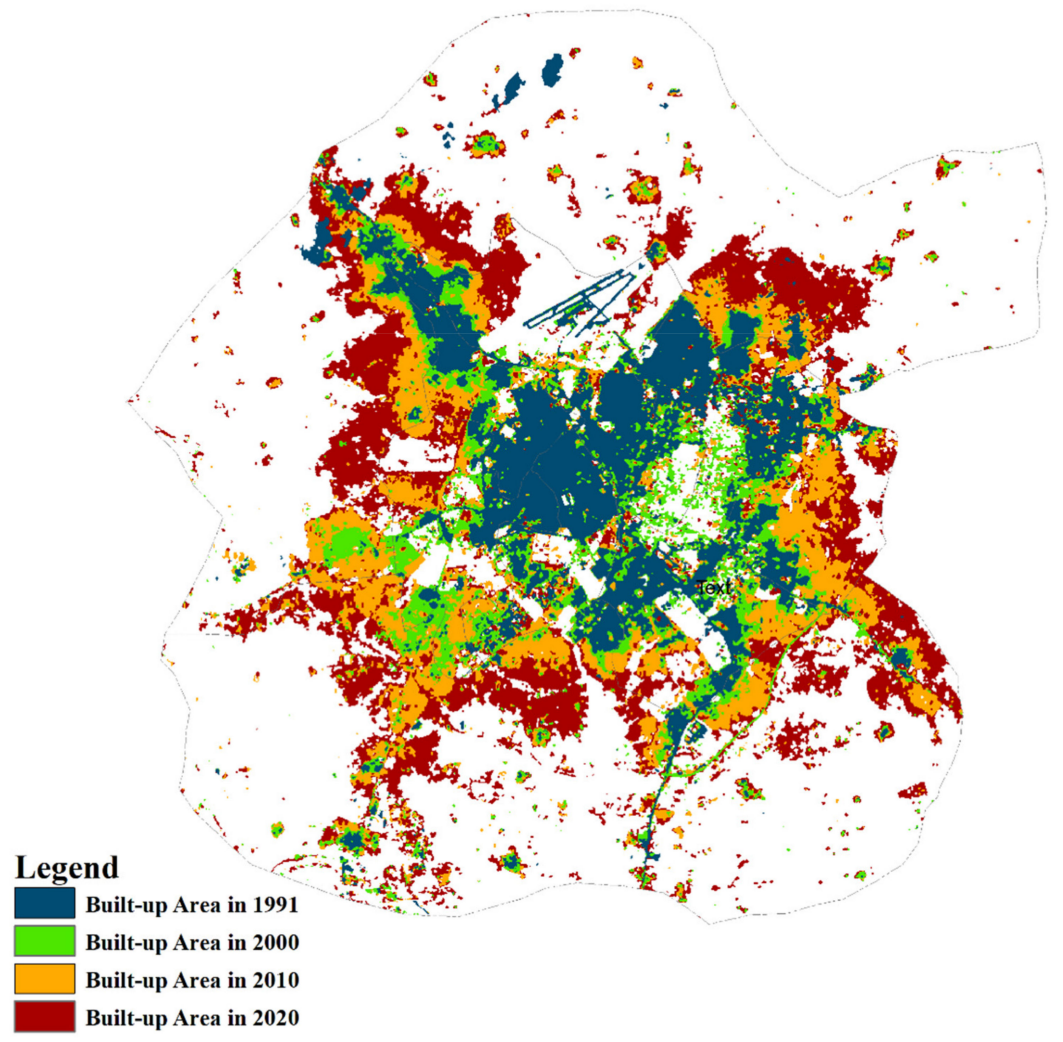

Figure 8. Urban Expansion of Kano Metropolis, Nigeria.

a.) NDVI Map of 1991

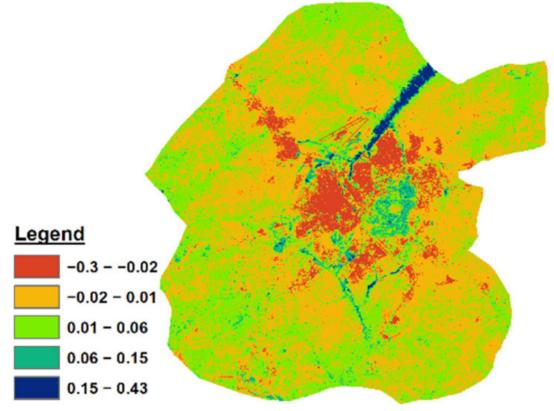

c.) NDVI Map of $\mathbf{2 0 1 0}$

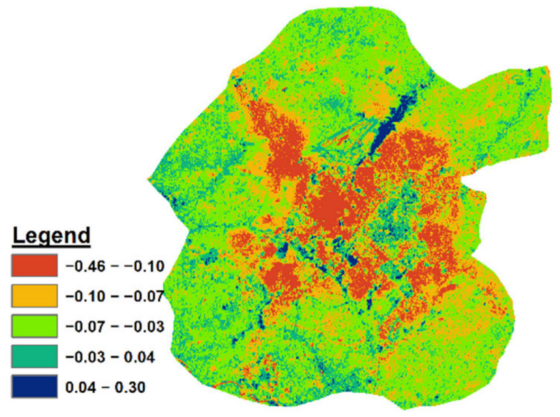

b.) NDVI Map of 2000

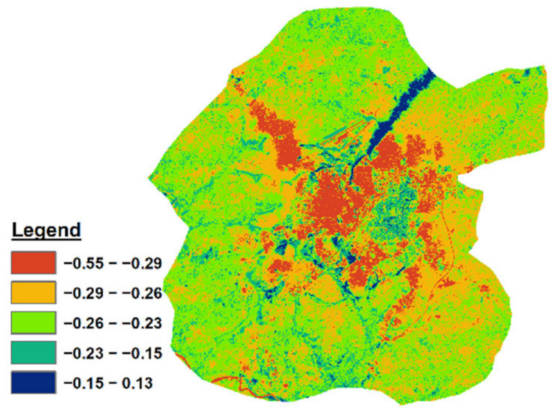

d.) NDVI Map of 2020

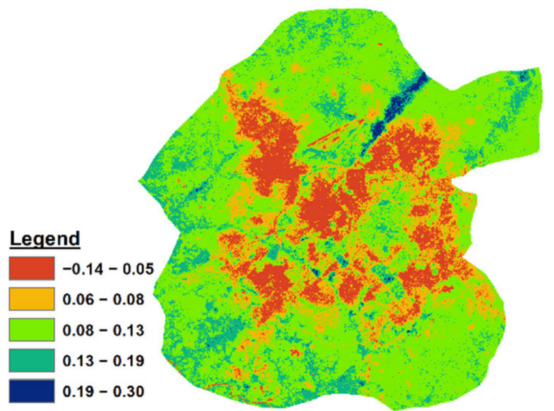

Figure 9. NDVI Maps of Kano Metropolis in (a) 1991, (b) 2000, (c) 2010, and (d) 2020. 


\subsection{Normalized Difference Built-Up Index}

The spectral index of the built-up area extraction was performed using NDBI and presented in Figure 10, which shows the NDBI maps for 1991, 2000, 2010, and 2020. The results indicate that NDBI values ranged from approximately -0.18 to +0.48 in 1991 . In 2000 , the lowest and highest NDBI values were -0.30 and +0.46 , respectively. The varying trend of NDBI continued in 2010 with minimum and maximum values of -0.48 and +0.52 , respectively. In 2020, the study area witnessed an NDBI value ranging between -0.25 and +0.35 . Furthermore, the results revealed a mean NDBI of 0.32 in 1991, 0.33 in 2000, 0.14 in 2010, and 0.06 in 2020. Therefore, the increase in the spatial coverage of built-up areas observed around the city's central core could be attributed to the outward growth and development of settlements.

\subsection{Land Surface Temperature}

The results of the study's LST, retrieved using the mono-window algorithm, is illustrated in Figure 11. It shows the variation of LST across Kano metropolis to be between $11.84^{\circ} \mathrm{C}$ and $33.30^{\circ} \mathrm{C}$ in 1991 . In 2000 , the LST values varied between $8.74{ }^{\circ} \mathrm{C}$ and $41.79{ }^{\circ} \mathrm{C}$, while in 2010 , they ranged from $2.18^{\circ} \mathrm{C}$ to $43.98^{\circ}$ and, finally, were between $16.77^{\circ} \mathrm{C}$ and $38.27^{\circ} \mathrm{C}$ in 2020 . These results indicate an increase in the city's minimum and maximum LST over the last three decades by approximately $4.93{ }^{\circ} \mathrm{C}$ and $4.97{ }^{\circ} \mathrm{C}$, respectively. It further reveals the mean LST of the study area to be about $30.32{ }^{\circ} \mathrm{C}, 33.96^{\circ} \mathrm{C}, 37.30^{\circ} \mathrm{C}$, and $31.24^{\circ} \mathrm{C}$ in $1991,2000,2010$, and 2020 , respectively.

a.) NDBI Map of 1991

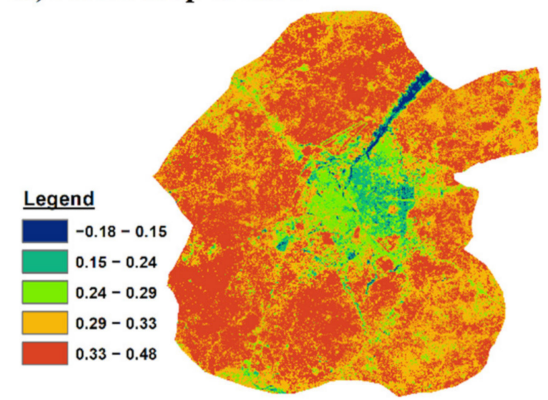

c.) NDBI Map of 2010

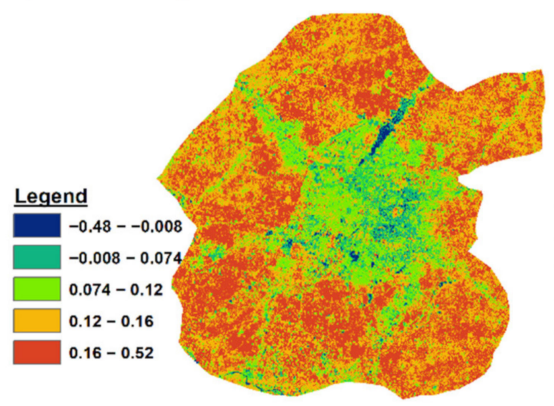

b.) NDBI Map of 2000

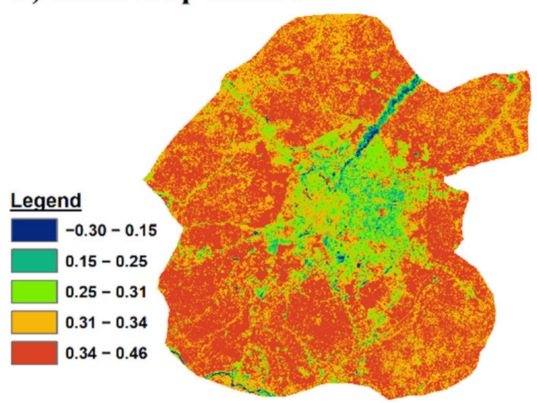

d.) NDBI Map of 2020

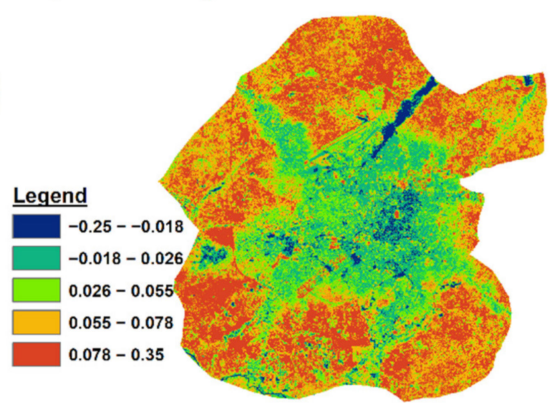

Figure 10. NDBI Maps of Kano Metropolis in (a) 1991, (b) 2000, (c) 2010, and (d) 2020. 
a.) LST Map of 1991

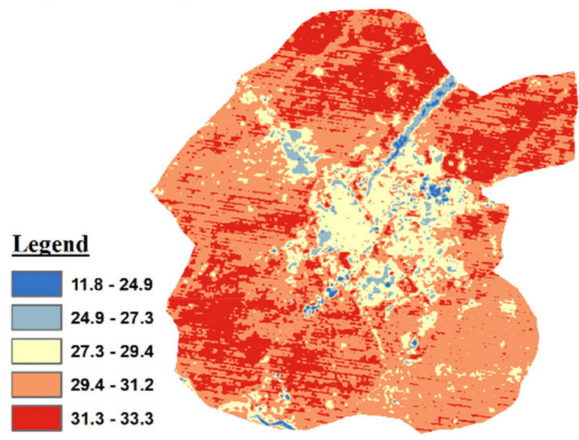

c.) LST Map of 2010

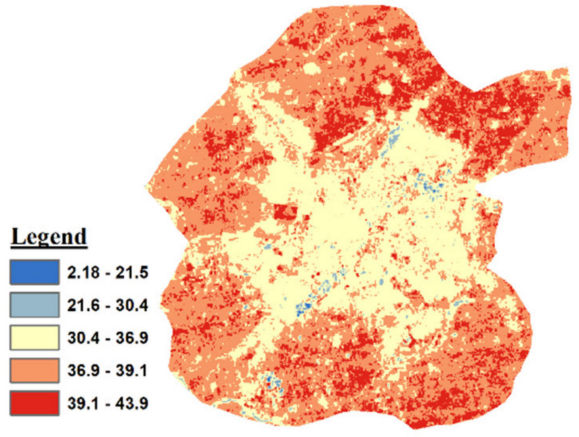

b.) LST Map of 2000

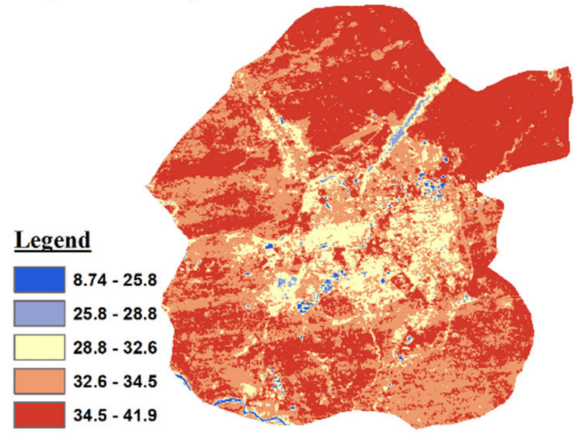

d.) LST Map of 2020

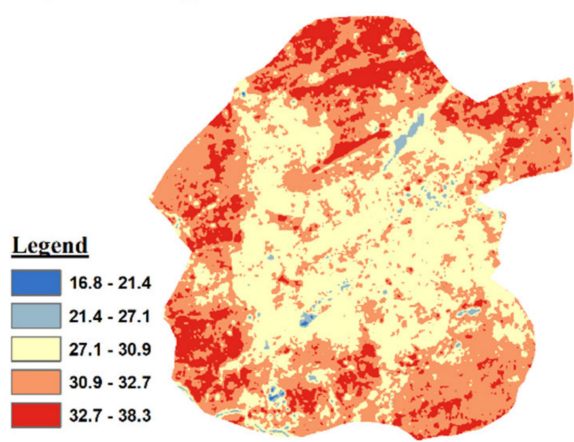

Figure 11. LST Maps of Kano Metropolis in (a) 1991, (b) 2000, (c) 2010, and (d) 2020.

\section{Implications of Land-Use Changes for Urban Climate}

To examine the influence of urbanization and LULC changes on the LST component of urban climate, thermal signatures of land use/land cover using spectral indices are essential [74]. Therefore, this study employed various sampling points to compare the relationship between LST and land spectral indices that include NDVI and NDBI. The correlation and regression coefficients were determined by considering the study area's land surface temperature as the dependent variable and the two spectral indices as the independent variable, i.e., vegetation cover index and built-up area index. The results of the linear correlation between LST and the land spectral indices, i.e., NDVI and NDBI, for the different years under consideration are presented in Figures 12 and 13. The Pearson's correlation clearly shows that LST is inversely related to NDVI and positively related to NDBI. These results indicate a negative relationship between the city's surface temperature (LST) and its vegetation index (NDVI), having a determination coefficient $\left(\mathrm{R}^{2}\right)$ of 0.6145 in 1991, 0.5644 in 2000, 0.5402 in 2010, and 0.5184 in 2020. The analysis of the linear regression line suggests that higher land surface temperatures were associated with areas of low vegetation cover, while lower land surface temperatures were observed in vegetated areas with high NDVI. The result further revealed a positive correlation between LST and NDBI, presenting a determination coefficient $\left(R^{2}\right)$ of $0.4132,0.3965,0.3907$, and 0.3300 in 1991, 2000, 2010, and 2020. 
a.) LST vs NDVI (1991)

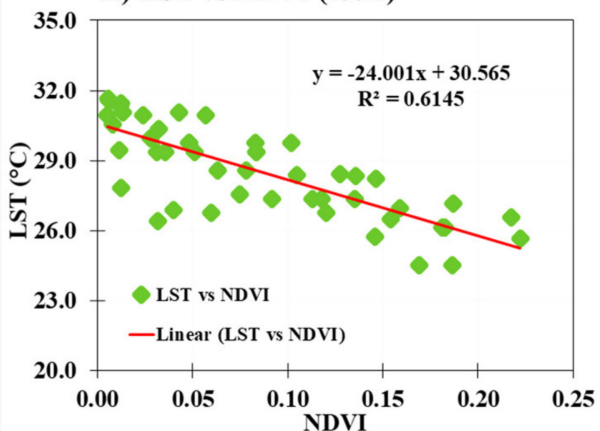

c.) LST vs NDVI (2010)

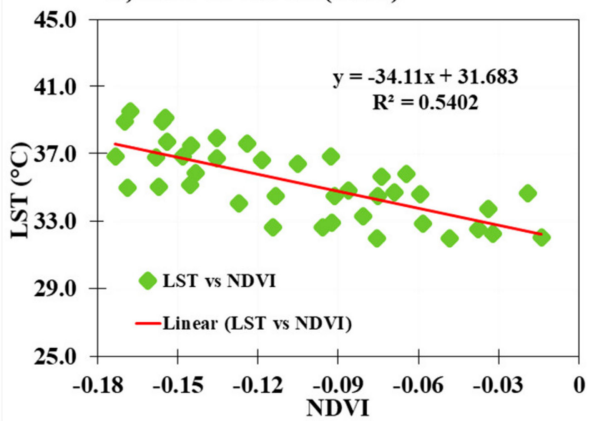

b.) LST vs NDVI (2000)

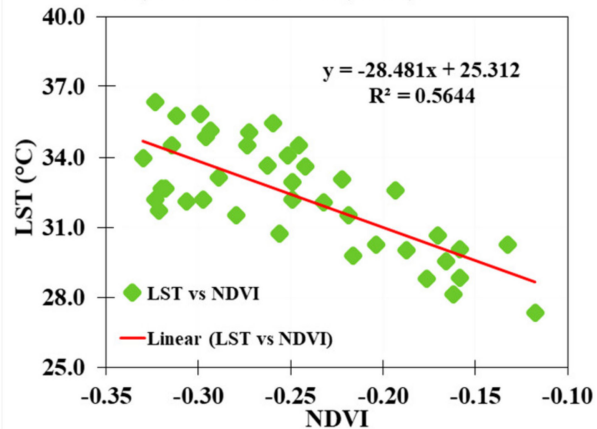

d.) LST vs NDVI (2020)

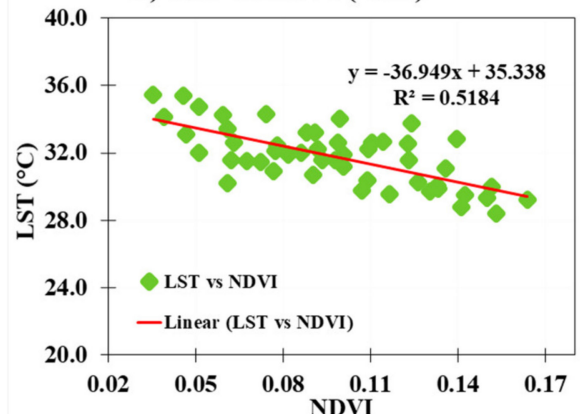

Figure 12. Correlation between LST and NDVI for the years (a) 1991, (b) 2000, (c) 2010, and (d) 2020.
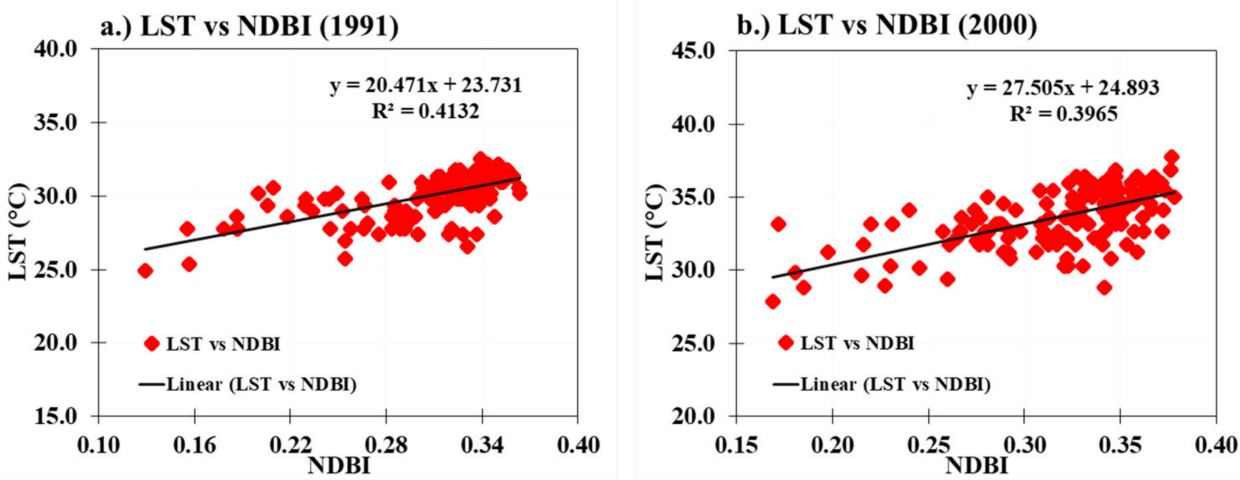

c.) LST vs NDBI (2010)

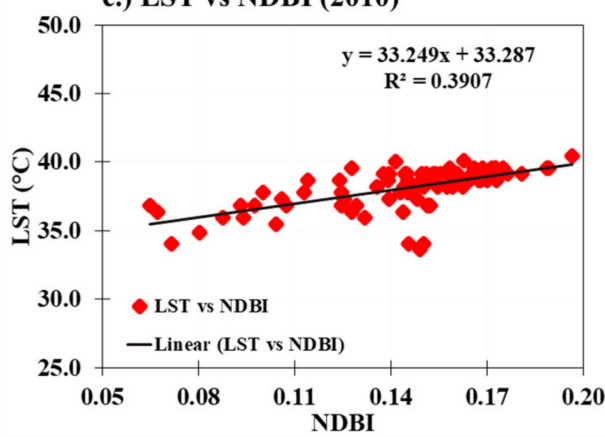

d.) LST vs NDBI (2020)

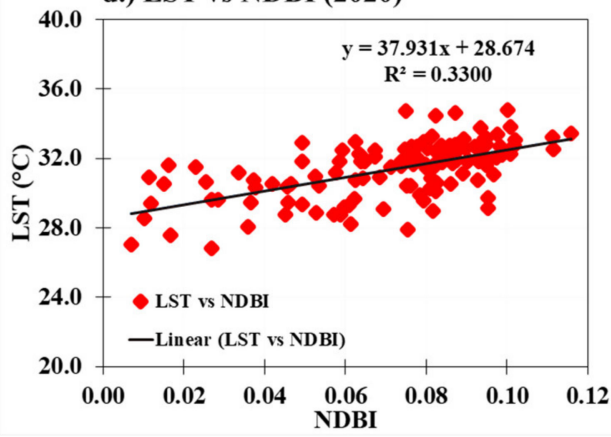

Figure 13. Correlation between LST and NDBI for the years (a) 1991, (b) 2000, (c) 2010, and (d) 2020.

These findings align with previous studies in some geographical regions that presented higher land surface temperatures in urban areas with impervious surfaces and lower 
temperatures in water bodies and agricultural lands $[40,66,75]$. The results of these studies revealed that urban expansion has led to the continuous loss of vegetated lands and the development of impervious surfaces. This has contributed to the higher LST experienced in some urban centers and cities due to the increased absorption of solar radiation and its conversion into heat $[74,76]$. The consequence of this development is the creation of urban heat islands that negatively affect urban dwellers. Therefore, the findings of this study, alongside the result of Figures 9-11, could help mitigate the effect of urban heat islands in Kano metropolis by identifying areas having a higher LST. A statistical test for significance level (alpha) was also conducted, which generally involved the setting of the null hypothesis $\left(\mathrm{H}_{0}\right)$ and an alternative hypothesis $\left(\mathrm{H}_{1}\right)$. In this study, the null hypothesis was the hypothesis of no correlation between the study's variables. It signifies the nonlinear relationship between land surface temperature values and spectral indices, i.e., NDVI and NDBI. The alternative hypothesis indicates the linear relationship between LST values and spectral indices. The null hypothesis is rejected when the $p$-value is less than or equal to $0.001(p \leq 0.001)$ [77]. The regression result indicates the $p$-values during the different study periods to be less than 0.001 (Tables A2-A9), suggesting a linear relationship between the study's variables and strong evidence against the null hypothesis. Therefore, NDVI and NDBI are statistically significant variables that influenced the LST of the Kano metropolis over the last three decades. The areas around the city's central core with built-up areas and urban facilities have higher LST due to the impervious surfaces that expose such areas to greater solar radiation. The findings align with recent studies which have opined that the modification of land use due to various socio-economic factors has influenced local climatic condition in urban areas $[6,73,78]$. Additional studies are therefore needed in order to forecast and mitigate the environmental consequences of such changes.

\section{Conclusions}

This study analysed the influence of rapid urbanization and the decadal changes in land uses on the urban climate of Kano Metropolis using satellite images from 1991, 2000, 2010, and 2020. The expansion of urban areas and the alteration of land uses were monitored from 1991 to 2020 . The relationship between LULC classes and land surface temperature was evaluated using spectral indices such as NDVI and NDBI. The study area witnessed substantial changes in the city's barren lands, built-up areas, vegetation, and water bodies due to the different push and pull factors that contributed to the urban expansion and socio-development of the city. The LULC change detection results for the last three decades revealed the city's built-up areas and vegetation to have increased by $18.59 \%$ and $5.67 \%$, respectively, while barren land and water bodies declined by $21.03 \%$ and $3.23 \%$, respectively. The spectral indices indicated higher NDVI in vegetated areas and lower NDVI in built-up areas and barren lands. The results also indicated an increase in the study area's land surface temperature, which could be attributed to the changes in land uses. Higher surface temperature values were witnessed in built-up areas and barren land, mainly due to the city's urban expansion and socio-economic development, which altered the study area's surface radiative properties. This phenomenon could also be attributed to the growing influence of climate change. However, further research is necessary to confirm this. The relationship between the LST component of urban climate and the thermal signature of land uses revealed a negative correlation between LST and NDVI values and a positive relationship between LST and NDBI values. High land surface temperatures were observed in areas with low vegetation cover and high urban development. Therefore, land surface temperature as an essential factor in urban climate are greatly influenced by the change dynamics of LULC. The study's findings would be of great use to urban planners and decision-makers in undertaking comprehensive measures aimed at planning urban growth in a rapidly growing metropolis. It will also assist in managing land uses by adopting sustainable and heat-resilient strategies that seek to mitigate the environmental challenges associated with urban climate. 
Author Contributions: Conceptualization, A.F.K.; methodology, A.F.K., and G.A.A.; software, A.F.K.; validation, G.A.A.; formal analysis, A.F.K.; data curation, R.H., and A.A.N.A.; writing-original draft preparation, A.F.K.; writing-review and editing, A.A.N.A. and G.A.A.; visualization, M.B.; supervision, Y.W.; project administration, Y.W.; funding acquisition, Y.W. All authors have read and agreed to the published version of the manuscript.

Funding: This research was supported by the National Natural Science Foundation of China (NSFC), grant number 51778559 (2018/01-2021/12).

Institutional Review Board Statement: Not applicable.

Informed Consent Statement: Not applicable.

Data Availability Statement: The data presented in this research article are available from the corresponding author (Y.W.) on request.

Acknowledgments: The authors would like to express sincere appreciation for the Bilateral Educational Agreement between the People's Republic of China and the Federal Government of Nigeria under which this study was carried out.

Conflicts of Interest: The authors declare no conflict of interest.

\section{Appendix A}

Table A1. Annual Mean Temperature $\left({ }^{\circ} \mathrm{C}\right)$ and Rainfall $(\mathrm{mm})$ Data for the study periods.

\begin{tabular}{cccccc}
\hline S/ & Study & $\begin{array}{c}\text { Temperature } \\
\text { (min.) }\end{array}$ & $\begin{array}{c}\text { Temperature } \\
\text { (max.) }\end{array}$ & $\begin{array}{c}\text { Average } \\
\text { Temperature }\end{array}$ & $\begin{array}{c}\text { Rainfall } \\
(\mathbf{m m})\end{array}$ \\
\hline 1. & Year & 19.88 & 33.20 & 26.54 & 1087.40 \\
2. & 1991 & 19.63 & 33.41 & 26.52 & 1109.00 \\
3. & 2000 & 20.84 & 34.37 & 27.61 & 1080.50 \\
4. & 2010 & 22.99 & 34.08 & 28.54 & 1050.90 \\
\hline
\end{tabular}

Note: $\min .=$ minimum and max. $=$ maximum. Source: Nigerian Meteorological Agency (NIMET).

Table A2. Regression Statistics between LST and NDVI for 1991.

(i) Regression Statistics

$\begin{array}{lc}\text { Multiple R } & 0.783869 \\ \text { R Square } & 0.61445 \\ \text { Adjusted R } & 0.606069 \\ \text { Square } & \\ \text { Standard } & 1.22293 \\ \text { Error } & 48 \\ \text { Observations } & \end{array}$

\begin{tabular}{|c|c|c|c|c|c|c|c|c|}
\hline \multicolumn{9}{|l|}{ (ii) ANOVA } \\
\hline & df & SS & MS & F & $\begin{array}{c}\text { Significance } \\
\text { F }\end{array}$ & & & \\
\hline \multirow{4}{*}{$\begin{array}{l}\text { Regression } \\
\text { Residual } \\
\text { Total }\end{array}$} & 1 & 109.6396 & 109.6396 & 73.31015 & $4.45 \times 10^{-11}$ & & & \\
\hline & 46 & 68.79567 & 1.495558 & & & & & \\
\hline & 47 & 178.4353 & & & & & & \\
\hline & Coefficients & $\begin{array}{c}\text { Standard } \\
\text { Error }\end{array}$ & t Stat & $p$-value & $\begin{array}{c}\text { Lower } \\
95 \%\end{array}$ & $\begin{array}{l}\text { Upper } \\
95 \%\end{array}$ & $\begin{array}{l}\text { Lower } \\
95.0 \%\end{array}$ & $\begin{array}{l}\text { Upper } \\
95.0 \%\end{array}$ \\
\hline Intercept & 30.56512 & 0.296372 & 103.1308 & $4.5 \times 10^{-56}$ & 29.96855 & 31.16168 & 29.96855 & 31.16168 \\
\hline 0.011494 & -24.0009 & 2.803144 & -8.56213 & $4.45 \times 10^{-11}$ & -29.6433 & -18.3585 & -29.6433 & -18.3585 \\
\hline
\end{tabular}


Table A3. Regression Statistics between LST and NDVI for 2000.

\begin{tabular}{|c|c|c|c|c|c|c|c|c|}
\hline \multicolumn{9}{|c|}{ (i) Regression Statistics } \\
\hline Multiple R & 0.75125 & & & & & & & \\
\hline R Square & 0.564377 & & & & & & & \\
\hline $\begin{array}{l}\text { Adjusted R } \\
\text { Square }\end{array}$ & 0.552913 & & & & & & & \\
\hline Standard & 1.532181 & & & & & & & \\
\hline Observations & 40 & & & & & & & \\
\hline \multicolumn{9}{|l|}{ (ii) ANOVA } \\
\hline & $\mathrm{df}$ & SS & MS & $\mathrm{F}$ & $\begin{array}{c}\text { Significance } \\
\text { F }\end{array}$ & & & \\
\hline Regression & 1 & 115.5745 & 115.5745 & 49.23135 & $2.34 \times 10^{-8}$ & & & \\
\hline Residual & 38 & 89.20803 & 2.34758 & & & & & \\
\hline \multirow[t]{2}{*}{ Total } & 39 & 204.7826 & & & & & & \\
\hline & Coefficients & $\begin{array}{l}\text { Standard } \\
\text { Error }\end{array}$ & t Stat & $p$-value & $\begin{array}{l}\text { Lower } \\
95 \%\end{array}$ & $\begin{array}{c}\text { Upper } \\
95 \%\end{array}$ & $\begin{array}{l}\text { Lower } \\
95.0 \%\end{array}$ & $\begin{array}{l}\text { Upper } \\
95.0 \%\end{array}$ \\
\hline Intercept & 25.31217 & 1.033444 & 24.49302 & $7.04 \times 10^{-25}$ & 23.22007 & 27.40426 & 23.22007 & 27.40426 \\
\hline-0.251852 & -28.4807 & 4.059099 & -7.01651 & $2.34 \times 10^{-8}$ & -36.6979 & -20.2635 & -36.6979 & -20.2635 \\
\hline
\end{tabular}

Table A4. Regression Statistics between LST and NDVI for 2010.

\begin{tabular}{|c|c|c|c|c|c|c|c|c|}
\hline \multicolumn{9}{|c|}{ (i) Regression Statistics } \\
\hline Multiple R & 0.734998 & & & & & & & \\
\hline R Square & 0.540223 & & & & & & & \\
\hline $\begin{array}{l}\text { Adjusted R } \\
\text { Square }\end{array}$ & 0.527796 & & & & & & & \\
\hline $\begin{array}{l}\text { Standard } \\
\text { Error }\end{array}$ & 1.504349 & & & & & & & \\
\hline Observations & 39 & & & & & & & \\
\hline \multicolumn{9}{|l|}{ (ii) ANOVA } \\
\hline & $\mathrm{df}$ & SS & MS & $\mathrm{F}$ & $\begin{array}{c}\text { Significance } \\
\text { F }\end{array}$ & & & \\
\hline Regression & 1 & 98.38396 & 98.38396 & 43.47373 & $9.92 \times 10^{-8}$ & & & \\
\hline Residual & 37 & 83.73347 & 2.263067 & & & & & \\
\hline \multirow[t]{2}{*}{ Total } & 38 & 182.1174 & & & & & & \\
\hline & Coefficients & $\begin{array}{l}\text { Standard } \\
\text { Error }\end{array}$ & t Stat & $p$-value & $\begin{array}{c}\text { Lower } \\
95 \%\end{array}$ & $\begin{array}{c}\text { Upper } \\
95 \%\end{array}$ & $\begin{array}{l}\text { Lower } \\
95.0 \%\end{array}$ & $\begin{array}{l}\text { Upper } \\
95.0 \%\end{array}$ \\
\hline Intercept & 31.68284 & 0.597515 & 53.02434 & $1.65 \times 10^{-36}$ & 30.47216 & 32.89352 & 30.47216 & 32.89352 \\
\hline-0.09278 & -34.1102 & 5.173338 & -6.59346 & $9.92 \times 10^{-8}$ & -44.5924 & -23.628 & -44.5924 & -23.628 \\
\hline
\end{tabular}


Table A5. Regression Statistics between LST and NDVI for 2020.

\begin{tabular}{|c|c|c|c|c|c|c|c|c|}
\hline \multicolumn{9}{|c|}{ (i) Regression Statistics } \\
\hline Multiple R & 0.720013 & & & & & & & \\
\hline R Square & 0.518419 & & & & & & & \\
\hline $\begin{array}{l}\text { Adjusted R } \\
\text { Square }\end{array}$ & 0.508173 & & & & & & & \\
\hline $\begin{array}{l}\text { Standard } \\
\text { Error }\end{array}$ & 1.211811 & & & & & & & \\
\hline Observations & 49 & & & & & & & \\
\hline \multicolumn{9}{|l|}{ (ii) ANOVA } \\
\hline & $\mathrm{df}$ & SS & MS & $\mathrm{F}$ & $\begin{array}{c}\text { Significance } \\
\text { F }\end{array}$ & & & \\
\hline Regression & 1 & 74.29841 & 74.29841 & 50.59529 & $5.51 \times 10^{-9}$ & & & \\
\hline Residual & 47 & 69.01878 & 1.468485 & & & & & \\
\hline \multirow[t]{2}{*}{ Total } & 48 & 143.3172 & & & & & & \\
\hline & Coefficients & $\begin{array}{l}\text { Standard } \\
\text { Error }\end{array}$ & t Stat & $p$-value & $\begin{array}{c}\text { Lower } \\
95 \%\end{array}$ & Upper 95\% & $\begin{array}{l}\text { Lower } \\
95.0 \%\end{array}$ & $\begin{array}{l}\text { Upper } \\
95.0 \%\end{array}$ \\
\hline Intercept & 35.33758 & 0.533072 & 66.29044 & $4.4 \times 10^{-48}$ & 34.26517 & 36.40998 & 34.26517 & 36.40998 \\
\hline 0.124093 & -36.9493 & 5.194582 & -7.11304 & $5.51 \times 10^{-9}$ & -47.3994 & -26.4991 & -47.3994 & -26.4991 \\
\hline
\end{tabular}

Table A6. Regression Statistics between LST and NDBI for 1991.

\begin{tabular}{|c|c|c|c|c|c|c|c|c|}
\hline \multicolumn{9}{|c|}{ (i) Regression Statistics } \\
\hline \multirow{6}{*}{$\begin{array}{l}\text { Multiple R } \\
\text { R Square } \\
\text { Adjusted R } \\
\text { Square } \\
\text { Standard } \\
\text { Error } \\
\text { Observations }\end{array}$} & 0.642842 & & & & & & & \\
\hline & 0.413246 & & & & & & & \\
\hline & 0.409334 & & & & & & & \\
\hline & 1127524 & & & & & & & \\
\hline & 1.127324 & & & & & & & \\
\hline & 152 & & & & & & & \\
\hline \multicolumn{9}{|l|}{ (ii) ANOVA } \\
\hline & df & SS & MS & $\mathrm{F}$ & $\begin{array}{c}\text { Significance } \\
\text { F }\end{array}$ & & & \\
\hline Regression & 1 & 134.3058 & 134.3058 & 105.6437 & $4.32 \times 10^{-19}$ & & & \\
\hline Residual & 150 & 190.6965 & 1.27131 & & & & & \\
\hline \multirow[t]{2}{*}{ Total } & 151 & 325.0023 & & & & & & \\
\hline & Coefficients & $\begin{array}{l}\text { Standard } \\
\text { Error }\end{array}$ & t Stat & $p$-value & $\begin{array}{l}\text { Lower } \\
95 \%\end{array}$ & $\begin{array}{l}\text { Upper } \\
95 \%\end{array}$ & $\begin{array}{l}\text { Lower } \\
95.0 \%\end{array}$ & $\begin{array}{l}\text { Upper } \\
95.0 \%\end{array}$ \\
\hline Intercept & 23.731 & 0.620979 & 38.21546 & $3.32 \times 10^{-79}$ & 22.50401 & 24.958 & 22.50401 & 24.958 \\
\hline 0.305439 & 20.47092 & 1.991662 & 10.27831 & $4.32 \times 10^{-19}$ & 16.53558 & 24.40626 & 16.53558 & 24.40626 \\
\hline
\end{tabular}


Table A7. Regression Statistics between LST and NDBI for 2000.

\begin{tabular}{|c|c|c|c|c|c|c|c|c|}
\hline \multicolumn{9}{|c|}{ (i) Regression Statistics } \\
\hline Multiple R & 0.629694 & & & & & & & \\
\hline R Square & 0.396514 & & & & & & & \\
\hline Adjusted R & 0392789 & & & & & & & \\
\hline Square & 0.392789 & & & & & & & \\
\hline $\begin{array}{l}\text { Standard } \\
\text { Error }\end{array}$ & 1.5119 & & & & & & & \\
\hline Observations & 164 & & & & & & & \\
\hline \multicolumn{9}{|l|}{ (ii) ANOVA } \\
\hline & df & SS & MS & $\mathrm{F}$ & $\begin{array}{c}\text { Significance } \\
\text { F }\end{array}$ & & & \\
\hline Regression & 1 & 243.3059 & 243.3059 & 106.4404 & $1.69 \times 10^{-19}$ & & & \\
\hline Residual & 162 & 370.3064 & 2.285842 & & & & & \\
\hline \multirow[t]{2}{*}{ Total } & 163 & 613.6122 & & & & & & \\
\hline & Coefficients & $\begin{array}{l}\text { Standard } \\
\text { Error }\end{array}$ & t Stat & $p$-value & $\begin{array}{l}\text { Lower } \\
95 \%\end{array}$ & $\begin{array}{l}\text { Upper } \\
95 \%\end{array}$ & $\begin{array}{l}\text { Lower } \\
95.0 \%\end{array}$ & $\begin{array}{l}\text { Upper } \\
95.0 \%\end{array}$ \\
\hline Intercept & 24.89345 & 0.865602 & 28.75855 & $1.56 \times 10^{-65}$ & 23.18413 & 26.60277 & 23.18413 & 26.60277 \\
\hline 0.309524 & 27.50474 & 2.665964 & 10.31699 & $1.69 \times 10^{-19}$ & 22.24022 & 32.76926 & 22.24022 & 32.76926 \\
\hline
\end{tabular}

Table A8. Regression Statistics between LST and NDBI for 2010.

\begin{tabular}{|c|c|c|c|c|c|c|c|c|}
\hline \multicolumn{9}{|c|}{ (i) Regression Statistics } \\
\hline Multiple R & 0.625042 & & & & & & & \\
\hline R Square & 0.390677 & & & & & & & \\
\hline $\begin{array}{l}\text { Adjusted R } \\
\text { Square }\end{array}$ & 0.383246 & & & & & & & \\
\hline Standard & 1.168795 & & & & & & & \\
\hline Observations & 84 & & & & & & & \\
\hline \multicolumn{9}{|l|}{ (ii) ANOVA } \\
\hline & df & SS & MS & $\mathrm{F}$ & $\begin{array}{c}\text { Significance } \\
\text { F }\end{array}$ & & & \\
\hline Regression & 1 & 71.8226 & 71.8226 & 52.57559 & $\begin{array}{l}2.08 \times \\
10^{-10}\end{array}$ & & & \\
\hline Residual & 82 & 112.0188 & 1.366083 & & & & & \\
\hline \multirow[t]{2}{*}{ Total } & 83 & 183.8414 & & & & & & \\
\hline & Coefficients & $\begin{array}{l}\text { Standard } \\
\text { Error }\end{array}$ & t Stat & $p$-value & $\begin{array}{l}\text { Lower } \\
95 \%\end{array}$ & Upper 95\% & $\begin{array}{l}\text { Lower } \\
95.0 \%\end{array}$ & $\begin{array}{l}\text { Upper } \\
95.0 \%\end{array}$ \\
\hline Intercept & 33.28701 & 0.671995 & 49.53458 & $\begin{array}{l}7.07 \times \\
10^{-63}\end{array}$ & 31.9502 & 34.62382 & 31.9502 & 34.62382 \\
\hline 0.142857 & 33.24926 & 4.585534 & 7.250902 & $\begin{array}{l}2.08 \times \\
10^{-10}\end{array}$ & 24.12717 & 42.37134 & 24.12717 & 42.37134 \\
\hline
\end{tabular}


Table A9. Regression Statistics between LST and NDBI for 2020.

\begin{tabular}{lc}
\hline (i) Regression Statistics \\
\hline Multiple R & 0.574441 \\
R Square & 0.329983 \\
Adjusted R & 0.324536 \\
$\begin{array}{l}\text { Square } \\
\text { Standard }\end{array}$ & 1.295586 \\
Error & 125 \\
Observations &
\end{tabular}

(ii) ANOVA

\begin{tabular}{|c|c|c|c|c|c|c|c|c|}
\hline & $\mathrm{df}$ & SS & MS & F & $\begin{array}{c}\text { Significance } \\
\text { F }\end{array}$ & & & \\
\hline Regression & 1 & 101.6817 & 101.6817 & 60.5774 & $2.48 \times 10^{-12}$ & & & \\
\hline Residual & 123 & 206.4607 & 1.678542 & & & & & \\
\hline \multirow[t]{2}{*}{ Total } & 124 & 308.1424 & & & & & & \\
\hline & Coefficients & $\begin{array}{l}\text { Standard } \\
\text { Error }\end{array}$ & t Stat & $p$-value & $\begin{array}{c}\text { Lower } \\
95 \%\end{array}$ & $\begin{array}{l}\text { Upper } \\
95 \%\end{array}$ & $\begin{array}{l}\text { Lower } \\
95.0 \%\end{array}$ & $\begin{array}{l}\text { Upper } \\
95.0 \%\end{array}$ \\
\hline Intercept & 28.6737 & 0.368658 & 77.77867 & $1.9 \times 10^{-106}$ & 27.94397 & 29.40344 & 27.94397 & 29.40344 \\
\hline 0.006878 & 37.93102 & 4.87348 & 7.783149 & $2.48 \times 10^{-12}$ & 28.28426 & 47.57777 & 28.28426 & 47.57777 \\
\hline
\end{tabular}

\section{References}

1. Hassan, M.M.; Nazem, M.N.I. Examination of land use/land cover changes, urban growth dynamics, and environmental sustainability in Chittagong city, Bangladesh. Environ. Dev. Sustain. 2016, 18, 697-716. [CrossRef]

2. Patra, S.; Sahoo, S.; Mishra, P.; Mahapatra, S.C. Impacts of urbanization on land use/cover changes and its probable implications on local climate and groundwater level. J. Urban Manag. 2018, 7, 70-84. [CrossRef]

3. Ukoje, J.E. Impacts of rapid urbanisation in the urban fringe of Lokoja, Nigeria. J. Geogr. Reg. Plan. 2016, 9, 185-194. [CrossRef]

4. Sharma, K. Urbanization Induced Land Use-Land Cover Changes in the Manipur Valley and Surrounding Hills: A Landscape Metrics Approach. In Environmental Change in the Himalayan Region: Twelve Case Studies; Saikia, A., Thapa, P., Eds.; Springer International Publishing: Cham, Switzerland, 2019; pp. 137-155. [CrossRef]

5. Parnell, S.; Walawege, R. Sub-Saharan African urbanisation and global environmental change. Glob. Environ. Chang. 2011, 21, S12-S20. [CrossRef]

6. Worku, G.; Teferi, E.; Bantider, A. Assessing the effects of vegetation change on urban land surface temperature using remote sensing data: The case of Addis Ababa city, Ethiopia. Remote. Sens. Appl. Soc. Environ. 2021, 22, 100520. [CrossRef]

7. Atasoy, M. Assessing the impacts of land-use/land-cover change on the development of urban heat island effects. Environ. Dev. Sustain. 2020, 22, 7547-7557. [CrossRef]

8. Gui, X.; Wang, L.; Yao, R.; Yu, D.; Li, C. Investigating the urbanization process and its impact on vegetation change and urban heat island in Wuhan, China. Environ. Sci. Pollut. Res. 2019, 26, 30808-30825. [CrossRef] [PubMed]

9. Ullah, S.; Tahir, A.A.; Akbar, T.A.; Hassan, Q.K.; Dewan, A.; Khan, A.J.; Khan, M. Remote Sensing-Based Quantification of the Relationships between Land Use Land Cover Changes and Surface Temperature over the Lower Himalayan Region. Sustainability 2019, 11, 5492. [CrossRef]

10. Grimm, N.B.; Faeth, S.H.; Golubiewski, N.E.; Redman, C.L.; Wu, J.; Bai, X.; Briggs, J.M. Global Change and the Ecology of Cities. Science 2008, 319, 756-760. [CrossRef] [PubMed]

11. Akbari, H.; Cartalis, C.; Kolokotsa, D.; Muscio, A.; Pisello, A.L.; Rossi, F.; Santamouris, M.; Synnefa, A.; Wong, N.H.; Zinzi, M. Local climate change and urban heat island mitigation techniques-The state of the art. J. Civ. Eng. Manag. 2016, $22,1-16$. [CrossRef]

12. Akbari, H.; Kolokotsab, D. Three decades of urban heat islands and mitigation technologies research. Energy Build. 2016, 133, 834-842. [CrossRef]

13. Miao, J.; Wu, X. Urbanization, socioeconomic status and health disparity in China. Health Place 2016, 42, 87-95. [CrossRef]

14. Chapman, S.; Watson, J.E.M.; Salazar, A.; Thatcher, M.; McAlpine, C.A. The impact of urbanization and climate change on urban temperatures: A systematic review. Landsc. Ecol. 2017, 32, 1921-1935. [CrossRef]

15. Li, D.; Bou-Zeid, E. Synergistic Interactions between Urban Heat Islands and Heat Waves: The Impact in Cities Is Larger than the Sum of Its Parts. J. Appl. Meteorol. Climatol. 2013, 52, 2051-2064. [CrossRef]

16. Coutts, A.; Beringer, J.; Tapper, N. Changing Urban Climate and CO2 Emissions: Implications for the Development of Policies for Sustainable Cities. Urban Policy Res. 2010, 28, 27-47. [CrossRef]

17. Prastiyo, S.E.; Irham; Hardyastuti, S.; Jamhari. How agriculture, manufacture, and urbanization induced carbon emission? The case of Indonesia. Environ. Sci. Pollut. Res. 2020, 27, 42092-42103. [CrossRef] 
18. Singh, S.K.; Srivastava, P.K.; Pandey, A.C.; Gautam, S.K. Integrated Assessment of Groundwater Influenced by a Confluence River System: Concurrence with Remote Sensing and Geochemical Modelling. Water Resour. Manag. 2013, 27, 4291-4313. [CrossRef]

19. Shahfahad; Talukdar, S.; Rihan, M.; Hang, H.T.; Bhaskaran, S.; Rahman, A. Modelling urban heat island (UHI) and thermal field variation and their relationship with land use indices over Delhi and Mumbai metro cities. Environ. Dev. Sustain. 2021. [CrossRef]

20. United Nations Department of Economic and Social Affairs. World Urbanization Prospects: The 2018 Revision. Available online: https:/ / esa.un.org/unpd/wup/ (accessed on 7 April 2021).

21. Koko, A.; Yue, W.; Abubakar, G.A.; Alabsi, A.A.N.; Hamed, R. Spatiotemporal Influence of Land Use/Land Cover Change Dynamics on Surface Urban Heat Island: A Case Study of Abuja Metropolis, Nigeria. ISPRS Int. J. Geo-Inf. 2021, $10,272$. [CrossRef]

22. Zhang, H.; Li, T.-T.; Han, J.-J. Quantifying the relationship between land use features and intra-surface urban heat island effect: Study on downtown Shanghai. Appl. Geogr. 2020, 125, 102305. [CrossRef]

23. Karakus, C. The Impact of Land Use/Land Cover (LULC) Changes on Land Surface Temperature in Sivas City Center and Its Surroundings and Assessment of Urban Heat Island. Asia-Pac. J. Atmos. Sci. 2019, 55, 669-684. [CrossRef]

24. Cai, Y.; Zhang, H.; Zheng, P.; Pan, W. Quantifying the Impact of Land use/Land Cover Changes on the Urban Heat Island: A Case Study of the Natural Wetlands Distribution Area of Fuzhou City, China. Wetlands 2016, 36, 285-298. [CrossRef]

25. Rousta, I.; Sarif, M.O.; Gupta, R.D.; Olafsson, H.; Ranagalage, M.; Murayama, Y.; Zhang, H.; Mushore, T.D. Spatiotemporal Analysis of Land Use/Land Cover and Its Effects on Surface Urban Heat Island Using Landsat Data: A Case Study of Metropolitan City Tehran (1988-2018). Sustainability 2018, 10, 4433. [CrossRef]

26. Sarif, M.O.; Rimal, B.; Stork, N.E. Assessment of Changes in Land Use/Land Cover and Land Surface Temperatures and Their Impact on Surface Urban Heat Island Phenomena in the Kathmandu Valley (1988-2018). ISPRS Int. J. Geo-Inf. 2020, 9, 726. [CrossRef]

27. Mandal, S.; Saha, A. Support vector machines for monitoring land use dynamicity and temporal variation of land surface temperature in Kurseong and surrounding of Darjeeling Himalaya. Modeling Earth Syst. Environ. 2018, 4, 659-672. [CrossRef]

28. Heinl, M.; Hammerle, A.; Tappeiner, U.; Leitinger, G. Determinants of urban-rural land surface temperature differences-A landscape scale perspective. Landsc. Urban Plan. 2015, 134, 33-42. [CrossRef]

29. Santamouris, M.; Cartalis, C.; Synnefa, A. Local urban warming, possible impacts and a resilience plan to climate change for the historical center of Athens, Greece. Sustain. Cities Soc. 2015, 19, 281-291. [CrossRef]

30. Kikon, N.; Singh, P.; Singh, S.K.; Vyas, A. Assessment of urban heat islands (UHI) of Noida City, India using multi-temporal satellite data. Sustain. Cities Soc. 2016, 22, 19-28. [CrossRef]

31. Ramachandra, T.V.; Bharath, A.H.; Sowmyashree, M.V. Monitoring urbanization and its implications in a mega city from space: Spatiotemporal patterns and its indicators. J. Environ. Manag. 2015, 148, 67-81. [CrossRef]

32. Luo, X.; Vahmani, P.; Hong, T.; Jones, A. City-Scale Building Anthropogenic Heating during Heat Waves. Atmosphere 2020, 11, 1206. [CrossRef]

33. Gorse, C.; Parker, J.; Thomas, F.; Fletcher, M.; Ferrier, G.; Ryan, N. The Planning and Design of Buildings: Urban Heat IslandsMitigation. In Industry 4.0 and Engineering for a Sustainable Future; Dastbaz, M., Cochrane, P., Eds.; Springer International Publishing: Cham, Switzerland, 2019; pp. 211-225. [CrossRef]

34. Joshi, R.; Raval, H.; Pathak, M.; Prajapati, S.; Patel, A.; Singh, V.; Kalubarme, M. Urban Heat Island Characterization and Isotherm Mapping Using Geo-Informatics Technology in Ahmedabad City, Gujarat State, India. Int. J. Geosci. 2015, 6, 274-285. [CrossRef]

35. Leal Filho, W.; Echevarria Icaza, L.; Neht, A.; Klavins, M.; Morgan, E.A. Coping with the impacts of urban heat islands. A literature based study on understanding urban heat vulnerability and the need for resilience in cities in a global climate change context. J. Clean. Prod. 2018, 171, 1140-1149. [CrossRef]

36. Phelan, P.; Kaloush, K.; Miner, M.; Golden, J.; Phelan, B.; Silva, H.; Taylor, R.A. Urban Heat Island: Mechanisms, Implications, and Possible Remedies. Annu. Rev. Environ. Resour. 2015, 40, 285-307. [CrossRef]

37. Dissanayake, D.; Morimoto, T.; Ranagalage, M.; Murayama, Y. Land-Use/Land-Cover Changes and Their Impact on Surface Urban Heat Islands: Case Study of Kandy City, Sri Lanka. Climate 2019, 7, 99. [CrossRef]

38. Gogoi, P.P.; Vinoj, V.; Swain, D.; Roberts, G.; Dash, J.; Tripathy, S. Land use and land cover change effect on surface temperature over Eastern India. Sci. Rep. 2019, 9, 8859. [CrossRef] [PubMed]

39. Khamchiangta, D.; Dhakal, S. Future urban expansion and local climate zone changes in relation to land surface temperature: Case of Bangkok Metropolitan Administration, Thailand. Urban Clim. 2021, 37, 100835. [CrossRef]

40. Ahmed, H.A.; Singh, S.K.; Kumar, M.; Maina, M.S.; Dzwairo, R.; Lal, D. Impact of urbanization and land cover change on urban climate: Case study of Nigeria. Urban Clim. 2020, 32, 100600. [CrossRef]

41. Peng, J.; Jia, J.; Liu, Y.; Li, H.; Wu, J. Seasonal contrast of the dominant factors for spatial distribution of land surface temperature in urban areas. Remote. Sens. Environ. 2018, 215, 255-267. [CrossRef]

42. Rizvi, S.H.; Fatima, H.; Alam, K.; Iqbal, M.J. The Surface Urban Heat Island Intensity and Urban Expansion: A comparative analysis for the coastal areas of Pakistan. Environ. Dev. Sustain. 2021, 23, 5520-5537. [CrossRef]

43. Tanko, I.A.; Suleiman, Y.M.; Yahaya, T.I.; Kasim, A.A. Urbanisation Effect on the Occurrence of Urban Heat Island over Kano Metropolis, Nigeria. Int. J. Sci. Eng. Res. 2017, 8, 293-299.

44. Barau, A.S. The Great Attractions Of Kano; Research and Documentation Directorate: Government House Kano, Nigeria, 2007. [CrossRef] 
45. Mohammed, M.; Abdulhamid, A.; Badamasi, M.; Ahmed, M. Rainfall Dynamics and Climate Change in Kano, Nigeria. J. Sci. Res. Rep. 2015, 7, 386-395. [CrossRef]

46. Ahmed, K. The Kano Physical Environment. In Perspectives on Kano; Adamu, A.U., Ado-Kurawa, I., Eds.; Telletes Press: Lagos, Nigeria, 2010; Volume 1, pp. 7-46.

47. Auwalu, F.K.; Wu, Y.; Ghali, A.A.; Roknisadeh, H.; Akram Ahmed, N.A. Analyzing urban growth and land cover change scenario in Lagos, Nigeria using multi-temporal remote sensing data and GIS to mitigate flooding. Geomat. Nat. Hazards Risk 2021, 12, 631-652. [CrossRef]

48. Shang, M.; Wang, S.-X.; Zhou, Y.; Du, C. Effects of Training Samples and Classifiers on Classification of Landsat-8 Imagery. J. Indian Soc. Remote. Sens. 2018, 46, 1333-1340. [CrossRef]

49. Keshtkar, H.; Voigt, W.; Alizadeh, E. Land-cover classification and analysis of change using machine-learning classifiers and multi-temporal remote sensing imagery. Arab. J. Geosci. 2017, 10, 154. [CrossRef]

50. Abubakar, G.; Wang, K.; Shahtahamssebi, A.; Xue, X.; Belete, M.; Abdallah, A.; Shuka, K.; Gan, M. Mapping Maize Fields by Using Multi-Temporal Sentinel-1A and Sentinel-2A Images in Makarfi, Northern Nigeria, Africa. Sustainability 2020, 12, 2539. [CrossRef]

51. Lamine, S.; Petropoulos, G.P.; Singh, S.K.; Szabó, S.; Bachari, N.E.I.; Srivastava, P.K.; Suman, S. Quantifying land use/land cover spatio-temporal landscape pattern dynamics from Hyperion using SVMs classifier and FRAGSTATS ${ }^{\circledR}$. Geocarto Int. 2018, 33, 862-878. [CrossRef]

52. Singh, S.K.; Srivastava, P.K.; Gupta, M.; Thakur, J.K.; Mukherjee, S. Appraisal of land use/land cover of mangrove forest ecosystem using support vector machine. Environ. Earth Sci. 2014, 71, 2245-2255. [CrossRef]

53. Singh, S.K.; Srivastava, P.K.; Szabó, S.; Petropoulos, G.P.; Gupta, M.; Islam, T. Landscape transform and spatial metrics for mapping spatiotemporal land cover dynamics using Earth Observation data-sets. Geocarto Int. 2017, 32, 113-127. [CrossRef]

54. Ayele, G.T.; Tebeje, A.K.; Demissie, S.S.; Belete, M.A.; Jemberrie, M.A.; Teshome, W.M.; Mengistu, D.T.; Teshale, E.Z. Time Series Land Cover Mapping and Change Detection Analysis Using Geographic Information System and Remote Sensing, Northern Ethiopia. Air Soil Water Res. 2018, 11, 1178622117751603. [CrossRef]

55. Rawat, J.S.; Kumar, M. Monitoring land use/cover change using remote sensing and GIS techniques: A case study of Hawalbagh block, district Almora, Uttarakhand, India. Egypt. J. Remote. Sens. Space Sci. 2015, 18, 77-84. [CrossRef]

56. Alam, A.; Bhat, M.S.; Maheen, M. Using Landsat satellite data for assessing the land use and land cover change in Kashmir valley. GeoJournal 2020, 85, 1529-1543. [CrossRef]

57. Haque, M.I.; Basak, R. Land cover change detection using GIS and remote sensing techniques: A spatio-temporal study on Tanguar Haor, Sunamganj, Bangladesh. Egypt. J. Remote. Sens. Space Sci. 2017, 20, 251-263. [CrossRef]

58. Congalton, R.G. A review of assessing the accuracy of classifications of remotely sensed data. Remote. Sens. Environ. 1991, 37, 35-46. [CrossRef]

59. Jensen, J.R. Introductory Digital Image Processing: A Remote Sensing Perspective; Upper Saddle River: New Jersey, USA, 2016 ; Volume 4.

60. Abubakar, G.A.; Wang, K.; Belete, M.; Shahtahamassebi, A.; Biswas, A.; Gan, M. Towards Digital Agricultural Mapping in Africa: Evidence of Northern Nigeria. Arab. J. Geosci. 2021, 14, 643. [CrossRef]

61. Koko, A.; Yue, W.; Abubakar, G.A.; Hamed, R.; Alabsi, A.A.N. Monitoring and Predicting Spatio-Temporal Land Use/Land Cover Changes in Zaria City, Nigeria, through an Integrated Cellular Automata and Markov Chain Model (CA-Markov). Sustainability 2020, 12, 10452. [CrossRef]

62. Barbieri, T.; Despini, F.; Teggi, S. A multi-temporal analyses of Land Surface Temperature using Landsat-8 data and open source software: The case study of Modena, Italy. Sustainability 2018, 10, 1678. [CrossRef]

63. Ranagalage, M.; Estoque, R.; Murayama, Y. An Urban Heat Island Study of the Colombo Metropolitan Area, Sri Lanka, Based on Landsat Data (1997-2017). Int. J. Geo-Inf. 2017, 6, 189. [CrossRef]

64. Rosa dos Santos, A.; Santos de Oliveira, F.; Gomes da Silva, A.; Gleriani, J.M.; Gonçalves, W.; Moreira, G.L.; Silva, F.G.; Branco, E.R.F.; Moura, M.M.; Gomes da Silva, R.; et al. Spatial and temporal distribution of urban heat islands. Sci. Total. Environ. 2017, 605-606, 946-956. [CrossRef] [PubMed]

65. Pal, S.; Ziaul, S. Detection of land use and land cover change and land surface temperature in English Bazar urban centre. Egypt. J. Remote. Sens. Space Sci. 2017, 20, 125-145. [CrossRef]

66. Balew, A.; Korme, T. Monitoring land surface temperature in Bahir Dar city and its surrounding using Landsat images. Egypt. J. Remote. Sens. Space Sci. 2020, 23, 371-386. [CrossRef]

67. Qin, Z.; Karnieli, A.; Berliner, P. A mono-window algorithm for retrieving land surface temperature from Landsat TM data and its application to the Israel-Egypt border region. Int. J. Remote. Sens. 2001, 22, 3719-3746. [CrossRef]

68. United States Geological Survey (USGS). Landsat 7 (L7) Data Users Handbook. Available online: https://www.usgs.gov/corescience-systems/nli/landsat/landsat-7-data-users-handbook (accessed on 11 November 2020).

69. United States Geological Survey (USGS). Landsat 8 (L8) Data Users Handbook. Available online: https:/ / www.usgs.gov/corescience-systems/nli/landsat/landsat-8-data-users-handbook (accessed on 11 November 2020).

70. Wilks, D.S. Statistical Methods in the Atmospheric Sciences, 2nd ed.; Elsevier Academic Press: Burlington, MA, USA, 2006.

71. Priyankara, P.; Ranagalage, M.; Dissanayake, D.; Morimoto, T.; Murayama, Y. Spatial Process of Surface Urban Heat Island in Rapidly Growing Seoul Metropolitan Area for Sustainable Urban Planning Using Landsat Data (1996-2017). Climate 2019, 7, 110. [CrossRef] 
72. Story, M.; Congalton, R.G. Accuracy assessment: A user's perspective. Photogramm. Eng. Remote. Sens. 1986, 52, $397-399$.

73. Hussain, S.; Karuppannan, S. Land use/land cover changes and their impact on land surface temperature using remote sensing technique in district Khanewal, Punjab Pakistan. Geol. Ecol. Landsc. 2021, 1-13. [CrossRef]

74. Imran, H.M.; Hossain, A.; Islam, A.K.M.S.; Rahman, A.; Bhuiyan, M.A.E.; Paul, S.; Alam, A. Impact of Land Cover Changes on Land Surface Temperature and Human Thermal Comfort in Dhaka City of Bangladesh. Earth Syst. Environ. 2021, 5, 667-693. [CrossRef]

75. Tan, J.; Yu, D.; Li, Q.; Tan, X.; Zhou, W. Spatial relationship between land-use/land-cover change and land surface temperature in the Dongting Lake area, China. Sci. Rep. 2020, 10, 9245. [CrossRef]

76. Traore, M.; Lee, M.S.; Rasul, A.; Balew, A. Assessment of land use/land cover changes and their impacts on land surface temperature in Bangui (the capital of Central African Republic). Environ. Chall. 2021, 4, 100114. [CrossRef]

77. Harrison, A.J.; McErlain-Naylor, S.A.; Bradshaw, E.J.; Dai, B.; Nunome, H.; Hughes, G.; Kong, P.W.; Vanwanseele, B.; Vilas-Boas, J.P.; Fong, D. Recommendations for statistical analysis involving null hypothesis significance testing. Sports Biomech. 2020, 19,561-568. [CrossRef]

78. Rahaman, S.; Jahangir; Haque, S.; Chen, R.; Kumar, P. Spatio-temporal changes of green spaces and their impact on urban environment of Mumbai, India. Environ. Dev. Sustain. 2021, 23, 6481-6501. [CrossRef] 